\title{
Synthesis and photophysical properties of multinuclear zinc-salophen complexes: enhancement of fluorescence by fluorene termini $\uparrow$
}

\author{
Kai-Lun Kuo, Chiung-Cheng Huang and Ying-Chih Lin*
}

\author{
Received 29th January 2008, Accepted 6th May 2008 \\ First published as an Advance Article on the web 18th June 2008 \\ DOI: 10.1039/b801602j
}

Incorporation of fluorene groups into the salicylidene moiety significantly enhances the luminescence of a number of multinuclear alkynylated $\mathrm{Zn}$ (II)-salophen complexes. Preparation of these complexes was achieved by a synthetic strategy with facile handling of the reactants, simple purification of the products, and one-pot reaction process. Two synthetic methods are used for the preparation of different types of multinuclear salophen complexes. The introduction of a bis- or a tris-salicylaldehyde as a bridging unit in the presence of various alkynyl substituted monoimines in the reaction mixture containing zinc acetate resulted in the preparation of di- and tri-nuclear $\mathrm{Zn}$ (II)-salophen complexes of type 1, respectively. For a different type, treatment of tetraminobenzene with various arylethynyl-substituted salicylaldehyde afforded dinuclear Zn(II) alkynylated salophen complexes of type 2 with a different structure. The photophysical behaviors of these multinuclear metal salophen complexes were investigated. Particularly, the dinuclear complex $9 \mathbf{b}$ of type 1 having ethynylfluorene groups in salophen moieties and dialkoxyl groups in the bridging moiety exhibits higher quantum efficiency than that of other complexes in this report. In addition, the bis- $\mathrm{Zn}$ (II) alkynylated salophen complex 11e bearing nitrogen donor groups displays more red-shifted pattern than those with other functional substituents both in absorption and emission spectra.

\section{Introduction}

Schiff-base complexes have received much attention recently, mainly because of their wide applications in the fields of synthesis and catalysis. Considerable research efforts are devoted to the synthesis of new complexes with transition ${ }^{1}$ and main group ${ }^{2}$ metal ions, to further develop their applications. ${ }^{3-7}$ Cooperative reactivity between multiple metal centers is commonly postulated for enzymatic systems ${ }^{8}$ and has evolved into an intriguing design principle for synthetic catalysts ${ }^{9}$ including Schiff-base complexes. Recently, Jacobsen and co-workers undertook the design of catalysts that enforce this cooperative mechanism through the construction of covalently linked bimetallic salen complexes, ${ }^{10}$ and application of such systems as highly enantioselective and efficient asymmetric ring opening catalysts has been achieved. Kinetic and enantioselectivity data provide evidence for the mechanism involving cooperative, intramolecular bimetallic catalysis. Metal salophen complexes have also been applied in the synthesis of macromolecules. The alkynylated salophen moiety was utilized to establish shape-persistent conjugated macrocycles with tunable pore diameters in the nanometer regime. ${ }^{11}$ These macrocycles can bind multiple metals, forming soluble, luminescent complexes. Moreover, Hupp and co-workers have developed a series of

Department of Chemistry, National Taiwan University, Taipei, Taiwan. E-mail: yclin@ntu.edu.tw; Fax: +(886)-2-23636359

$\dagger$ Electronic supplementary information (ESI) available: Fig. S1-S7: ${ }^{1} \mathrm{H}$ NMR spectra of complexes $7 \mathbf{b}, \mathbf{8 b}, 9 \mathbf{9}, \mathbf{9 b}, \mathbf{1 1 a}, 11 \mathbf{d}$ and 15a. Table S1: Comparison of the photophysical properties with energy gap for complexes 9-13 by MO calculation. Table S2: Molecular orbital calculations of dinuclear Zn(II)-salophen complexes. See DOI: 10.1039/b801602j bifunctional salophen type ligands to serve as building blocks for cyclic supramolecular structures. ${ }^{12}$ Previously, we reported the synthesis of alkynylated metal salophen complexes and investigated their photophysical properties. ${ }^{13}$ Introduction of a pyridyl group as a bridge as well as incorporation of ethynyl tethers and electron-donating groups into the salicylidene moiety of these complexes generally enhances the quantum yield of photoluminescence. These structural modifications cause a larger $\pi$ delocalization over the salicylidene and the aromatic bridging rings than that in regular $\mathrm{Zn}$ (salophen) complexes. The rigidity of the structure and the dipole moment of the complex may thus increase. In the preparation of $\mathrm{Mg}$ (II)-salophen complexes we unexpectedly obtained organic monoimines ${ }^{13 b, 14}$ which are considered as good precursors for the synthesis of unsymmetrical or polynuclear Schiff base complexes. Fluorenes are widely used as electron acceptors in charge transfer complexes ${ }^{15}$ and electron transport materials. ${ }^{16}$ The substituted poly(2,7-fuorene) derivatives are particularly desirable as active constituents of organic light-emitting diodes (OLEDs) due to their thermal and chemical stability and their high emission quantum yield. ${ }^{17}$ The fluorene structural moiety also provides a planar biphenyl unit within the molecular backbone. In this paper, we introduce fluorene group into a monoimine moiety to incorporate with various bridging units for the synthesis of two types of dinuclear Zn(II) alkynylated salophen complexes. Furthermore, we also use tris-salicylaldehydes to prepare trinuclear complexes. Upon inclusion of different substituted-arylethynyl groups including 2-ethynylfluorene derivatives and various bis-salicylaldehydes as bridge units of salophen moieties, the synthesis of these complexes and their photophysical properties are investigated. 


\section{Results and discussion}

\section{Synthesis of dinuclear $\mathrm{Zn}(\mathrm{II})$-salophen complexes}

Three bis(salicylaldehyde) compounds 1, 2 and 3 (Chart 1) were synthesized by $\mathrm{Pd}(\mathrm{II}) / \mathrm{Cu}(\mathrm{I})$ catalyzed Sonogashira crosscoupling reaction ${ }^{18}$ of 5-ethynylsalicylaldehyde with 1,4-bis(dodecyloxy-2,5-diiodo)benzene, 5-bromosalicylaldehyde and 2,5-diiodothiophene, respectively. ${ }^{19}$ Additionally, a bis-salicylaldehyde 4 (Chart 1) was prepared by the reaction of trioxane and salicylaldehyde in glacial acetic acid and sulfuric acid following the literature report. ${ }^{20}$ These compounds were readily purified by silica gel packed column chromatography and were isolated in about $30-80 \%$ yield. In the ${ }^{1} \mathrm{H}$ NMR spectra of these salicylaldehydes, resonances of the hydroxyl proton are observed at around $\delta_{\mathrm{H}} 11.1$ and resonances near $\delta_{\mathrm{H}} 9.9$ are assigned to the aldehyde group. In the ${ }^{13} \mathrm{C}$ NMR spectra, resonance of two carbonyl groups exhibits only one peak at $\delta_{\mathrm{C}} 192.7$ and similar results are observed for the alkynyl carbons indicating a symmetrical structure. Other spectroscopic data are also consistent with the proposed structure.

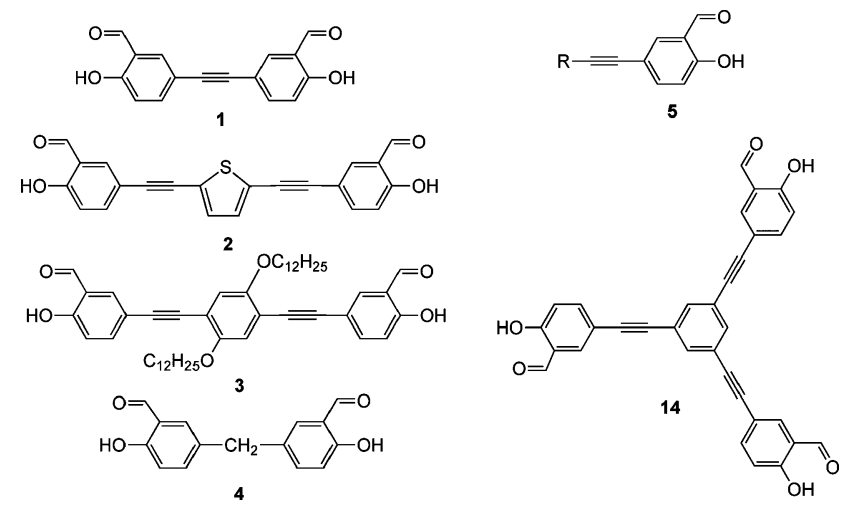

Chart 1 Structures of precusors 1-5 and 14.

A zinc-mediated, one-pot procedure provides access to a number of multinuclear $\mathrm{Zn}$ (II)-salophen complexes with functional groups displaying various steric and electronic effects. The procedure used for our preparation is slightly different from the methods reported in the literature. ${ }^{13 b}$ We first prepared the organic monoimine 6a by the reaction of 5-substituted ethynylsalicyaldehyde 5a with excess 2,3-diaminopyridine in a THF$\mathrm{MeOH}$ solution. Likewise monoimine compounds $\mathbf{6 b}$ and $\mathbf{6 c}$ were also successfully prepared in high yield. To prepare complex 7a, $\mathrm{Zn}(\mathrm{OAc})_{2}$ was directly treated with the bis-salicylaldehyde $\mathbf{1}$ in a THF-MeOH solution at $60{ }^{\circ} \mathrm{C}$. Subsequently the resulting reaction mixture was added slowly to a solution of $\mathbf{6 a}$ in THF, the mixture was stirred at $60{ }^{\circ} \mathrm{C}$ to give the orange product $7 \mathbf{a}$ which was collected by filtration in $70 \%$ yield (Scheme 1).

For $7 \mathbf{a}$, two resonances of the two imine $\mathrm{CH}=\mathrm{N}$ groups at $\delta_{\mathrm{H}}$ 9.45, 9.13 in the ${ }^{1} \mathrm{H}$ NMR spectrum and at $\delta_{\mathrm{C}} 164.7$ and 164.4 in the ${ }^{13} \mathrm{C}$ NMR spectrum, are consistent with $D_{2 \mathrm{~h}}$ symmetry for the bis-Zn(II)-salophen complex. In addition, three ethynyl carbons are observed at $\delta_{\mathrm{C}} 95.2,88.7$ and 81.3 in the ${ }^{13} \mathrm{C}$ NMR spectrum. The MALDI-TOF mass spectrum shows the parent ion at $\mathrm{m} / \mathrm{z}$ 996.38, supporting the structure of complex 7a.

In an effort to investigate the influence of the bridge in between two salicylaldehyde groups and the substituents in ethynylsalicylaldehyde, we used different bridging bis(salicylaldehyde)

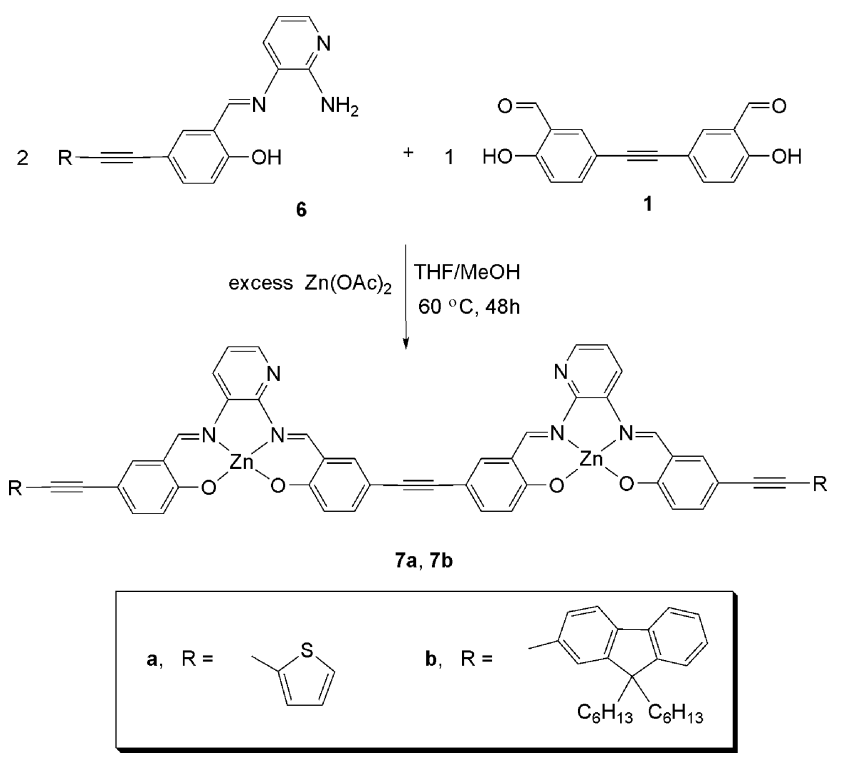

Scheme 1 Synthesis of dinuclear $\mathrm{Zn}$ (II)-salophen complexes of type I.

compounds 2, 3 and $\mathbf{4}$ to react with monoimine $\mathbf{6 a}$ having the ethynylthiophene group to prepare three dinuclear $\mathrm{Zn}$ (II)-salophen complexes 8a, 9a and 10a, respectively (Chart 2). Similarly three other dinuclear salophen complexes $\mathbf{7 b}, \mathbf{8 b}$ and $\mathbf{9 b}$ with an ethynylfluorene group were also prepared from the reactions of 6b with bis(salicylaldehyde) 1, 2 and 3, respectively. In general, these complexes were obtained in $45-70 \%$ yields. Two ${ }^{1} \mathrm{H}$ NMR absorptions of non-equivalent imine $\mathrm{CH}=\mathrm{N}$ protons are observed for these complexes.

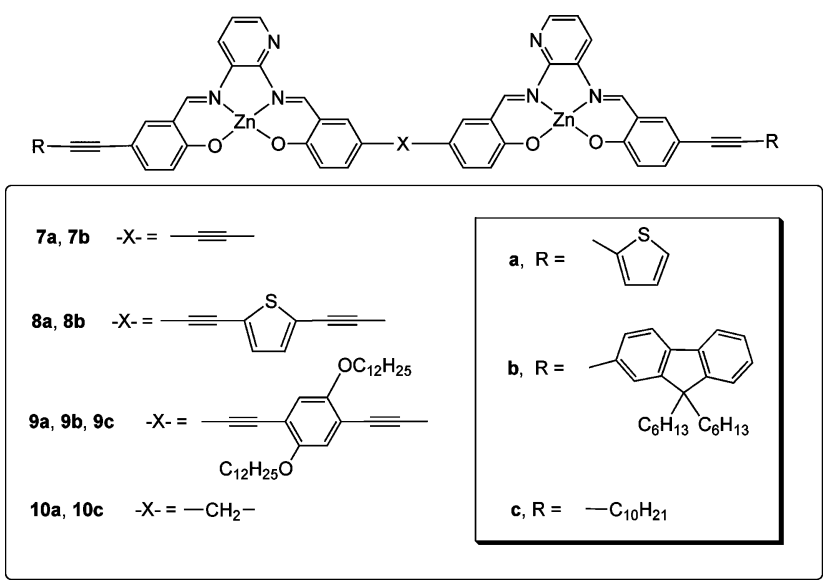

Chart 2 Structures of dinuclear $\mathrm{Zn}$ (II)-salophen complexes of type 1.

The one-pot reaction strategy for the preparation of mononuclear $\mathrm{Zn}$ (II)-salophen complexes is used for the synthesis of dinuclear Zn(II)-salophen complexes in which two salophen moieties are linked by a phenyl ring (see Scheme 2). The procedure involves the treatment of zinc acetate with 5-ethynylsalicylaldehyde in a mixed $\mathrm{MeOH}-\mathrm{THF}$ solvent for $30 \mathrm{~min}$ at $60^{\circ} \mathrm{C}$. After subsequent addition of 1,2,4,5-tetraaminobenzene tetrahydrochloride, the resulting solution was further stirred for 2 days to yield a red powder identified as complex 11d in 70\% isolated yield (Scheme 2). 

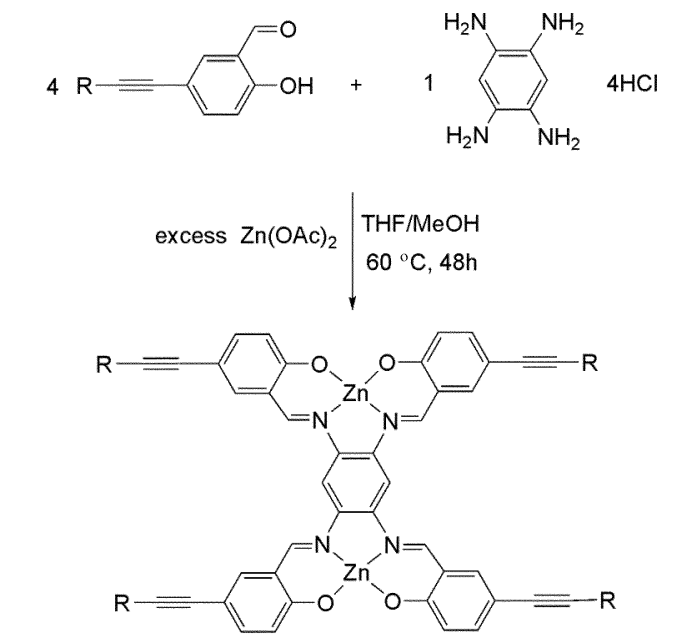

$11 \mathrm{a}, 11 \mathrm{~b}, 11 \mathrm{~d}, 11 \mathrm{e}$

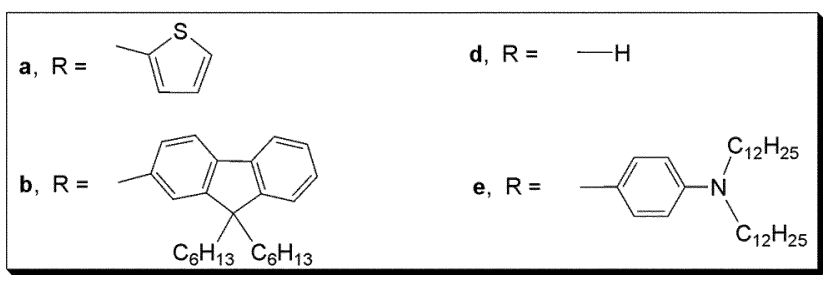

Scheme 2 Synthesis of dinuclear Zn(II)-salophen complexes of type 2.

In the ${ }^{1} \mathrm{H}$ NMR spectrum of complex 11d, a resonance of the imine groups is observed at $\delta_{\mathrm{H}} 9.15$ and a resonance of the bridging phenyl protons adjacent to two electron-withdrawing imine groups is at $\delta_{\mathrm{H}} 8.30$. Additionally, the singlet peak at $\delta_{\mathrm{H}} 3.91$ is assigned to the acetylenic protons. In the ${ }^{13} \mathrm{C}$ NMR spectrum, resonances of two ethynyl carbons are found in the range of $\delta_{\mathrm{C}} 74-94$. Other spectroscopic data are consistent with the proposed structure of 11d. Following the same procedure, a number of bimetallic complexes 11a, 11b and 11e bearing alkynylated substituents as well as alkyne-free analogues $\mathbf{1 2}$ and $\mathbf{1 3}$ were also prepared (Chart 3).

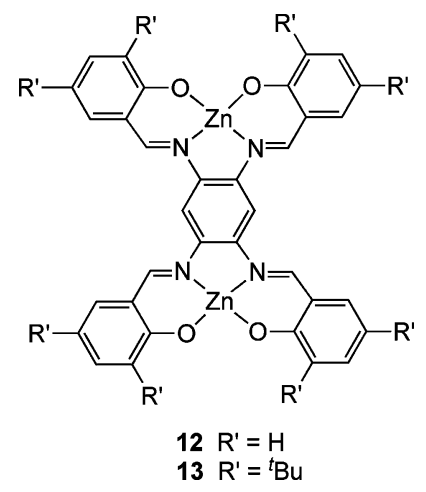

Chart 3 Structures of complexes $\mathbf{1 2}$ and $\mathbf{1 3}$.

Reek and co-workers have reported that dinuclear $\mathrm{Zn}$ (II)salophen complexes containing alkyne-free moieties can be obtained by a stepwise approach. ${ }^{14}$ In their preparation, free salophen ligands were first prepared by condensation of amines and aldehydes in alcohol solvent. Subsequently, metal acetate was introduced into the isolated salophen compound to afford the
bis-Zn(II)-salophen complex. Their attempts to use a one-pot approach yielded only mixtures of unidentified species. In our system, we can successfully utilize our one-pot methodology to afford dinuclear $\mathrm{Zn}$ (II)-salophen complexes 11, 12 and 13 with no side products such as oligomers or polymers. Therefore, our simple one-pot preparation procedure provides an alternative for the synthesis of dinuclear $\mathrm{Zn}$ (II)-salophen complexes.

\section{Synthesis of trinuclear $\mathrm{Zn}$ (II)-salophen complexes}

Under the same reaction condition as that utilized for the synthesis of dinuclear complexes, two trinuclear alkynylated salophen complexes 15a and 15b were also synthesized using suitable ratios of reactants. The precursor trisalicylaldehyde $\mathbf{1 4}$ is a rigid compound in which the conformational freedom is limited to the rotation about the single bonds between the ethynyl and the salicylaldehyde groups. Compound $\mathbf{1 4}$ was obtained from the reaction of 1,3,5-triethynylbenzene and 5-bromosalicylaldehyde using Sonogashira coupling reaction. Compound $\mathbf{1 4}$ dissolved in a mixture of pyridine and THF was then treated with $\mathrm{Zn}(\mathrm{OAc})_{2}$ and $\mathbf{6 a}$ in pyridine and $\mathrm{MeOH}$ to give the trinuclear complex 15a. By using the same procedure, complex $\mathbf{1 5} \mathbf{b}$ was also prepared in $50 \%$ yield (Scheme 3 ).
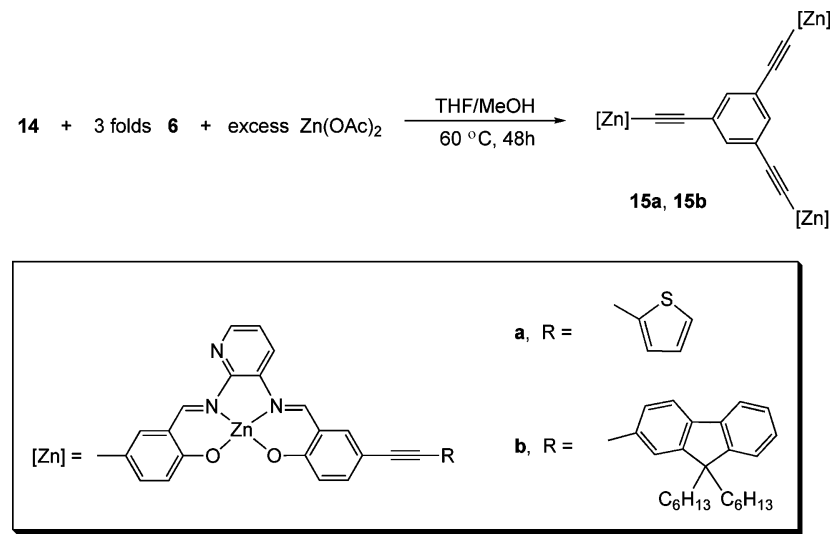

Scheme 3 Synthesis of trinuclear Zn(II)-salophen complexes.

The ${ }^{1} \mathrm{H}$ NMR spectrum of $\mathbf{1 5 a}$ shows two signals at $\delta 9.45$ and 9.13 attributed to two nonequivalent imine protons. The ${ }^{13} \mathrm{C} \mathrm{NMR}$ spectrum reveals the two imine carbon resonances at $\delta 163.8$ and $\delta$ 162.8, and four ethynyl carbons are also observed at $\delta$ 93.7, $91.8,85.5,79.9$. No signals for aldehyde and amino protons are detected, eliminating the possibility for the formation of monoor di-nuclear Zn(II)-salophen complexes. However, we were not able to obtain mass spectrum of these trinuclear $\mathrm{Zn}$ (II)-salophen complexes.

Previously, the analogous ethynyltrisalicylaldehyde, 1,3,5-tris[(5-tert-butyl-3-formyl-4-hydroxyphenyl)ethynyl]benzene ${ }^{21}$ was applied in the synthesis of rigid chiral Mn(II)-salophen polymers. These polymers catalyzed the asymmetric epoxidation of alkenes to give the corresponding epoxides up to $67 \%$ ee. Additionally, these complexes were reusable several times without reduced activity or selectivity. 
Table 1 Photophysical properties of dinuclear and trinuclear $\mathrm{Zn}$ (II)-salophen complexes

\begin{tabular}{|c|c|c|c|}
\hline Compounds & Absorption, $\lambda_{\max } / \mathrm{nm}\left(10^{-4} \varepsilon / \mathrm{M}^{-1} \mathrm{~cm}^{-1}\right)$ & Emission, $\lambda_{\max } / \mathrm{nm}$ & Quantum yield, $\Phi_{\mathrm{em}}{ }^{a}$ \\
\hline $7 \mathbf{a}$ & $482^{b}(7.577), 437$ (9.842), 343 (30.394), 327 (32.873), 296 (24.107) & 559.0 & 0.06 \\
\hline $7 \mathbf{b}$ & $487^{b}(3.090), 448(3.591), 358(11.803), 341(14.117), 295(8.740)$ & 558.6 & 0.13 \\
\hline $8 \mathbf{b}$ & $487^{b}(6.606), 444(7.007), 360(22.843), 345(21.726), 294(13.950)$ & 552.6 & 0.68 \\
\hline 9a & $485^{b}(3.535), 431(4.480), 383(8.445), 328(10.831), 290(8.564)$ & 555.6 & 0.28 \\
\hline 9b & $487^{b}(4.121), 447(4.184), 362(15.234), 346(15.554), 293(8.559)$ & 554.4 & 0.72 \\
\hline $9 c$ & $487^{b}(1.059), 441(1.215), 379(2.230), 324(1.768), 271(3.194)$ & 555.6 & 0.54 \\
\hline $11 \mathrm{a}$ & $519^{b}(3.336), 327(5.749)$ & 563.4 & 0.19 \\
\hline 11b & $522^{b}(6.935), 361(17.740), 342(17.954)$ & 567.6 & 0.35 \\
\hline 11d & $501^{b}(19.612), 323(10.102), 287(27.750)$ & 547.4 & 0.31 \\
\hline 11e & $531^{b}(6.606), 328(22.484)$ & 596.6 & 0.03 \\
\hline 12 & $495^{b}(14.601), 325(8.402), 260(10.825)$ & 535.0 & 0.06 \\
\hline 13 & $520^{b}(22.271), 499$ (22.022), 335 (12.877), 260 (12.668) & 560.0 & 0.31 \\
\hline 15a & $472^{b}(8.670), 431(10.423), 336(31.889)$ & 539.4 & 0.18 \\
\hline
\end{tabular}

${ }^{a}$ Referenced to $\left[\mathrm{Ru}^{\mathrm{II}}(\text { bipy })_{3}\right] \mathrm{Cl}_{2} .{ }^{b}$ Excitation wavelength for emission.

\section{Photophysical properties of multinuclear complexes}

Relevant photophysical properties of multinuclear Zn(II)-salophen complexes studied in this work are listed in Table 1. Absorption and emission spectra of dinuclear $\mathrm{Zn}$ (II)-salophen complexes 710 are shown in Fig. 1 and Fig. 2. Two distinct absorption bands in the range of $250-490 \mathrm{~nm}$ for the complexes are listed in Table 1 . The high energy absorption band is assigned to the ligandcentered (LC) $\pi-\pi^{*}$ transition of the $p$-substituted phenyl ring and salicylaldimine ligand. ${ }^{22}$ The low energy absorption band is assigned to the intramolecular charge transfer (ICT) band possibly relating to the phenoxide lone pair (l) and the $\pi^{*}$ orbital of imine, i.e. $\left[1(\right.$ phenoxide $) \rightarrow \pi^{*}($ imine $\left.\left.)\right)\right] .{ }^{22 b}$

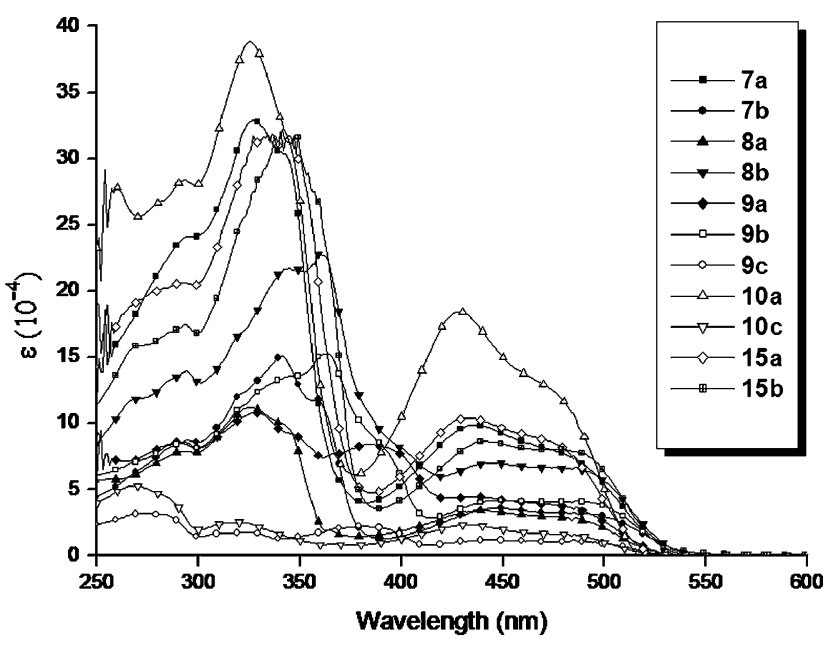

Fig. 1 Absorption spectra of the type 1 dinuclear $\mathrm{Zn}$ (II)-salophen complexes $7 \mathbf{a}-10 \mathbf{a}$ and trinuclear $15 \mathbf{a}$ and $\mathbf{1 5 b}$ in THF.

In general, the absorption and emission peaks of multinuclear $\mathrm{Zn}$ (II)-salophen complexes are more red-shifted than those of previously reported mononuclear-Zn(II) alkynylated salophen complexes. In the dinuclear $\mathrm{Zn}$ (II)-salophen complex of type 1, the variation of substituent group in the ethynyl side chains seems not to greatly influence the absorption and the emission

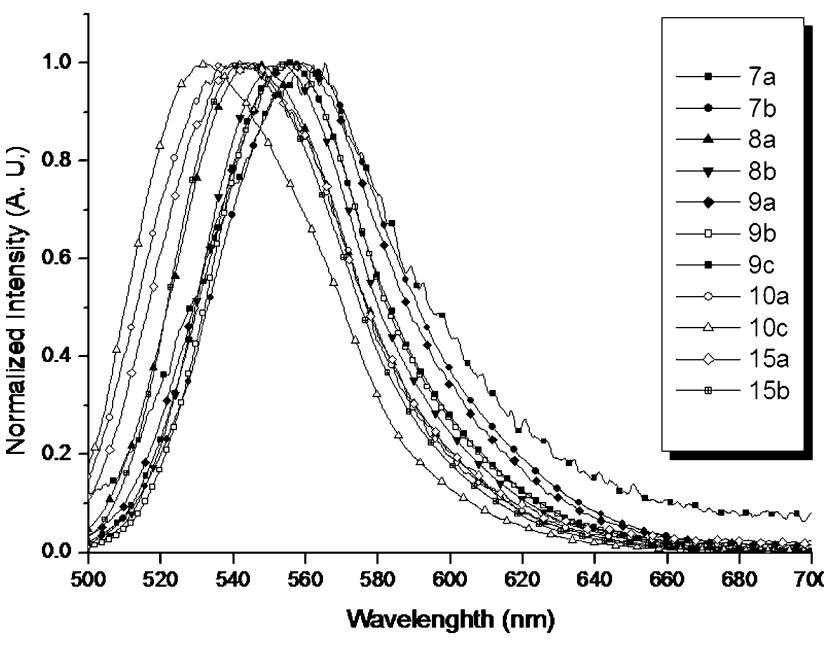

Fig. 2 Emission spectra of the type 1 dinuclear $\mathrm{Zn}$ (II)-salophen complexes $7 \mathbf{a}-10 \mathbf{a}$ and trinuclear $15 \mathbf{a}$ and $\mathbf{1 5 b}$ in THF.

patterns. For example, complexes 9a-9c show almost the same peaks at $487 \mathrm{~nm}$ in the absorption spectra and the same emission peaks at around $555 \mathrm{~nm}$. The quantum yield of 0.72 for $9 \mathbf{b}$ with alkylfluorene and bis-alkoxylbenzene moieties is higher than those of the other complexes. However, complexes $\mathbf{7 a}$ and $\mathbf{7 b}$, each with only one ethynyl linkage, show poorer quantum efficiency than other dinuclear $\mathrm{Zn}$ (II)-salophen complexes with two alkynyl linkages. For 10a and 10c in which two salophen groups are bridged by a methylene group, even though the absorption patterns are similar to those of other dinuclear complexes of type 1 , the emission spectra are slightly blue-shifted $20 \mathrm{~nm}$ relative to those of other complexes. When the side chains are fixed with thiophene groups, the absorption spectra of complexes 7a, 8a, 9a and 10a show similar character in the low energy band with the absorption band located at around $485 \mathrm{~nm}$. Especially, the absorption peaks of 11a in which two salophen moieties are linked by a phenyl ring display $c a$. $25 \mathrm{~nm}$ red-shift relative to those of type 1. Particularly, the two salophen moieties bridged with a methylene group in complex 10 lower $\pi$ delocalization between two salophen moieties 
relative to that of the other di- $\mathrm{Zn}$ (II)-salophen complexes $\mathbf{7 ,}, \mathbf{8}$, 9 and $\mathbf{1 1}$ described in this paper. This suggests that the $\mathrm{CH}_{2}$ bridge between two $\mathrm{Zn}$ (II)-salophen moieties might lower the rigidity of the structure and thus decrease the dipole moment of the complex. Additionally, from theoretical calculation (see ESI $\dagger$ ), the HOMO and LUMO frontier orbitals of complexes 7-9 generally show large electron density around the bridge moiety and salophen moiety, respectively. However, the HOMO frontier orbitals of complexes 10a and 10c exhibit major electron density in the region of ethynyl side chains and phenoxide moieties even though the LUMO frontier orbitals of them are similar to those of complexes 7-9. Moreover, the HOMO and LUMO energy gap in complexes 10a and 10c are smaller in comparison with those of complexes 7-9. Accordingly, the emission peak of complex 10a at $537 \mathrm{~nm}$ is slightly blue-shifted relative to those of other complexes. Attractively, complexes $\mathbf{7 b}, \mathbf{8 b}$ and $\mathbf{9 b}$ bearing fluorene groups all exhibit relatively higher quantum yield. This means that the incorporation of ethynylfluorene chromophores into the salophen moiety slightly enhances the quantum efficiency of di$\mathrm{Zn}$ (II)-salophen complexes. Similarly, this phenomenon could also be observed both in dinuclear $\mathrm{Zn}$ (II) complexes of type 2 and our trinuclear-Zn(II) complex systems.

Absorption and emission spectra for dinuclear Zn(II)-salophen complexes of type 2 are shown in Fig. 3 and 4, respectively. As to the ethynyl-free complexes $\mathbf{1 2}$ and $\mathbf{1 3}$, the quantum yield of $\mathbf{1 3}$ is higher than that of $\mathbf{1 2}$. The electron-donating tert-butyl groups in $\mathbf{1 3}$ enhance the quantum efficiency and bathochromic shift on both absorption and emission peaks relative to that of 12. The electron-donating tert-butyl group could increase the electron density in the excited states and enhance the probability of fluorescence relaxation. Additionally, four tert-butyl groups in complex $\mathbf{1 3}$ provide good shielding of the $\mathrm{Zn}$ (II)-salophen complex from solvent interactions thus leading to nonradiative deactivation. The steric bulk of the butyl group might also block the intermolecular stacking ${ }^{22}$ and decrease the self-quenching effect thus enhancing the quantum efficiency. Moreover, the absorption peaks for the ethynyl-substituted complexes 11a, 11b, 11d and 11e are red-shifted, contrasting with those for the two ethynyl-free analogues 12 and 13. Correspondingly, this trend

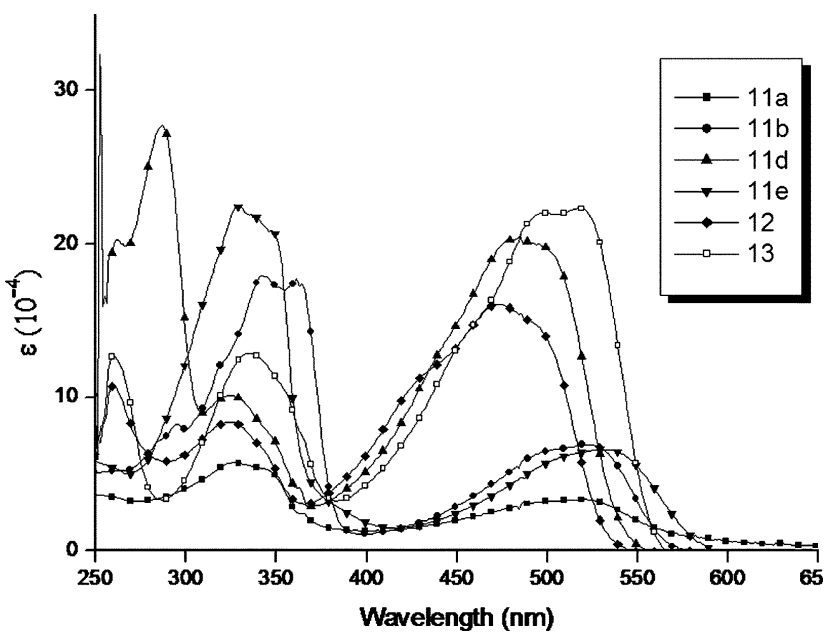

Fig. 3 Absorption spectra of the type 2 dinuclear $\mathrm{Zn}$ (II)-salophen complexes 11-13 in THF.

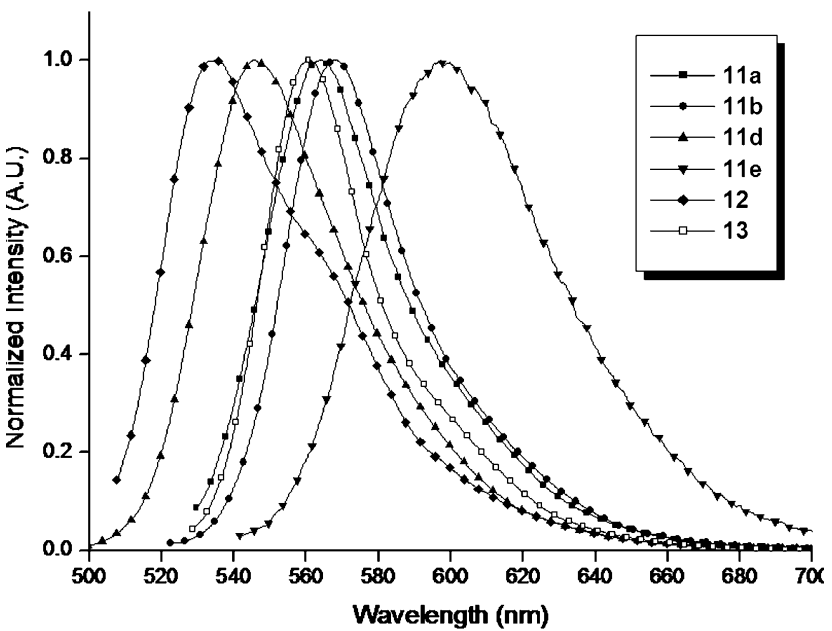

Fig. 4 Emission spectra of the type 2 dinuclear Zn(II)-salophen complexes 11-13 in THF.

could also be observed by the comparison of the HOMO and LUMO energy gap for complexes 11-13 in the MO calculation (see ESI $†$ ). Concerning ethynyl-substituted complexes of type 2, both absorption and emission spectra of complexes 11a, 11b and 11e with arylethynyl-substituted groups are more blue-shifted than those of complex 11d with alkynyl groups. These complexes with a larger $\pi$ delocalization over the salicylidene and aromatic rings possibly result in the enhancement of the structural rigidity. The aforementioned effects from the substituents are similar to those described in our previous reports. ${ }^{13}$ The absorption and emission bands for dinuclear $\mathrm{Zn}$ (II)-salophen complexes of type 2 are observed to red shift in comparison with that in mononuclear $\mathrm{Zn}$ (II)-salophen complexes. Particularly, the presence of nitrogen donor groups in complex 11e results in larger red shift, $c a .35 \mathrm{~nm}$ in absorption spectrum and $c a$. $60 \mathrm{~nm}$ in emission spectrum relative to substituent free complex $\mathbf{1 2}$.

Concerning the lifetime of the excitation state, complexes $9 \mathbf{b}$ and 11b, of which the quantum yields are higher than other complexes in this report, were further examined to gain insights into the relaxation dynamics in solution. For electrooptical applications of $\mathrm{Zn}$ (II)-salophen complexes, the observed lifetimes of $\mathbf{9 b}$ and $\mathbf{1 1 b}$ were measured to be 2.16 and $1.43 \mathrm{~ns}$, respectively, in THF.

\section{Conclusion}

In summary, we utilize various monoimines and bis- or trissalicylaldehyde or tetraminobenzene to synthesize a series of diand trinuclear-Zn(II)-salophen complexes. The methodology used for the synthesis of these complexes is simple and efficient. With regard to the photophysical properties, introduction of ethynylfluorene groups in salophen moieties and dialkoxyl groups in the bridging moiety significantly enhances the quantum efficiency of these complexes. In both absorption and emission spectra, dinuclear Zn(II)-salophen complexes of type 2 i.e. complexes 11-13, exhibit slightly red-shifted bands in comparison with those of type 1 i.e. complexes 7-10. Additionally, both absorption and emission peaks of the bis-Zn(II) alkynylated salophen complex 11e having nitrogen donor groups displays a more red-shifted pattern than 11a, 11b and 11d with other functional substituents. Furthermore, multinuclear Zn(II)-salophen complexes show slightly red-shifted 
bands from those of the corresponding mononuclear $\mathrm{Zn}$ (II)salophen complexes in both absorption and emission spectra.

\section{Experimental}

\section{General procedures}

All manipulations were performed under nitrogen using vacuumline, dry-box, and standard Schlenk techniques. $\mathrm{Et}_{3} \mathrm{~N}$ was dried from $\mathrm{KOH}, \mathrm{MeOH}$ from $\mathrm{Mg}$ turnings and THF from $\mathrm{Na} / \mathrm{ketyl}$. All other solvents and reagents were of reagent grade and were used without further purification. NMR spectra were recorded on Bruker AC-300, AVANCE-400 and DMX-500SB FT-NMR spectrometers at room temperature (unless states otherwise) and were reported in units of with residual protons in the solvent as standard $\left(\mathrm{CDCl}_{3}, \delta 7.24 ; d_{6}\right.$-methyl sulfoxide, $\delta 2.49 ; d_{8}$-THF, $\left.\delta 3.58,1.73\right)$. EI and FAB mass spectra were recorded on a VG70-250S mass spectrometer and JEOL SX-102A spectrometers, respectively. MALDI-TOF mass spectra were obtained in a dithranol matrix and collected by Voyager DE-PRO (Applied Biosystem, Houston, USA) equipped with a nitrogen laser $(337 \mathrm{~nm})$, and operated in the delayed extraction reflector mode. Absorption spectra were obtained using a HP8453, Hewlett-Packard UV-visible spectrophotometer. Emission spectra were taken using a Hitachi F-4500 luminescence spectrometer. Luminescence quantum yield $\left(\Phi_{\mathrm{em}}\right)$ were calculated relative to $\left[\mathrm{Ru}^{\mathrm{II}}(\mathrm{bipy})_{3}\right] \mathrm{Cl}_{2}$ in air-equilibrated aqueous solution $\left(\Phi_{\mathrm{em}}=0.028\right) .{ }^{23}$ Elemental analyses were carried on a Perkin-Elmer $2400 \mathrm{CHN}$ elemental analyzer. Preparation of monoimines $\mathbf{6 a}$ and $\mathbf{6 c}$ have been reported by us. ${ }^{13 b} 1,3,5-$ Triethynylbenzen $e^{24}$ and compound $\mathbf{4}^{21}$ were prepared by methods reported in the literatures. Quantum mechanical calculations were performed with the Spartan 04, version 1.0.8, software package. All HOMO and LUMO orbitals energy calculations were carried out by using the AM1 semi-empirical model. Lifetime studies were performed using an Edinburgh FL 900 photon-counting system with a hydrogen-filled/or a nitrogen lamp as the excitation source. Data were analyzed using the nonlinear least squares procedure in combination with an iterative convolution method. The emission decays were analyzed by the sum of exponential functions, which allows partial removal of the instrument time broadening and consequently renders a temporal resolution of $\sim 200 \mathrm{ps}$.

\section{Synthesis}

Compound 1. Under a nitrogen atmosphere, 5-bromosalicylaldehyde (412 mg, $2.05 \mathrm{mmol})$, 5-ethynylsalicylaldehyde $(100 \mathrm{mg}$, $0.68 \mathrm{mmol}), \mathrm{PPh}_{3}(4 \mathrm{mg}, 0.015 \mathrm{mmol})$ and $\mathrm{Pd}\left(\mathrm{PPh}_{3}\right)_{2} \mathrm{Cl}_{2}(11 \mathrm{mg}$, $0.016 \mathrm{mmol}$ ) were dissolved in $10 \mathrm{~mL}$ of THF. Then $5 \mathrm{~mL}$ of $\mathrm{Et}_{3} \mathrm{~N}$ was added, turning the solution from yellow to orange. After stirring for $20 \mathrm{~min}, \mathrm{CuI}(3 \mathrm{mg}, 0.016 \mathrm{mmol}$ ) was added, and the solution turned to dark brown. After heating at reflux at $70{ }^{\circ} \mathrm{C}$ for $48 \mathrm{~h}$, the solution was cooled to room temperature. The yellow precipitate thus formed was isolated by filtration and washed with cold dichloromethane. Yield: $54 \mathrm{mg} \mathrm{(30 \%} \mathrm{yield} \mathrm{based}$ on 5-ethynylsalicylaldehyde). Spectroscopic data of 1: ${ }^{1} \mathrm{H}$ NMR $\left(\mathrm{CDCl}_{3}\right) \delta 11.10(\mathrm{~s}, 2 \mathrm{H}, \mathrm{OH}), 9.88(\mathrm{~s}, 2 \mathrm{H}, \mathrm{CHO}), 7.73(\mathrm{~s}, 2 \mathrm{H}$, $\mathrm{ArH}), 7.64\left(\mathrm{~d}, 2 \mathrm{H}, \mathrm{ArH},{ }^{3} J_{\mathrm{H}-\mathrm{H}}=8.4 \mathrm{~Hz}\right), 6.98(\mathrm{~d}, 2 \mathrm{H}, \mathrm{ArH}$, $\left.{ }^{3} J_{\mathrm{H}-\mathrm{H}}=8.4 \mathrm{~Hz}\right) \cdot{ }^{13} \mathrm{C} \mathrm{NMR}\left(\mathrm{CDCl}_{3}\right): \delta 192.7(\mathrm{CHO}), 162.6,150.3$, $136.2,134.5,118.9,115.2(\mathrm{Ph}), 88.6(\mathrm{C} \equiv \mathrm{C})$. MS (FAB): $m / z 267.2$
$\left(\mathrm{M}^{+}+1\right)$. Anal. Calc. for $\mathrm{C}_{16} \mathrm{H}_{10} \mathrm{O}_{4}: \mathrm{C}, 72.18 ; \mathrm{H}, 3.79$. Found: $\mathrm{C}$, $72.26 ; \mathrm{H}, 3.83 \%$.

Compound 2. To a solution of 2,5-diiodothiophene $(460 \mathrm{mg}$, $1.37 \mathrm{mml})$ in $\mathrm{THF}-\mathrm{Et}_{3} \mathrm{~N}(20 \mathrm{~mL} / 10 \mathrm{~mL})$ under nitrogen was added a mixture of 5-ethynylsalicylaldehyde ( $500 \mathrm{mg}, 3.42 \mathrm{mmol}$ ), $\mathrm{Pd}\left(\mathrm{PPh}_{3}\right)_{2} \mathrm{Cl}_{2}(96 \mathrm{mg}, 0.14 \mathrm{mmol})$ and $\mathrm{CuI}(26 \mathrm{mg}, 0.14 \mathrm{mmol})$. The solution was stirred at $65^{\circ} \mathrm{C}$ for $18 \mathrm{~h}$. After the solution was cooled to room temperature, the solvent was removed by a rotary evaporator. The residue was purified by flash chromatography on silica gel eluted with EA-hexanes, $1: 3$ first, then EA as eluent on a short plug of silica gel. The solvent was removed in vacuum to give a brown powder. The product was washed by methanol and hexanes to yield $2(160 \mathrm{mg}, 31 \%)$. Spectroscopic data of $2:{ }^{1} \mathrm{H}$ NMR $\left(\mathrm{CDCl}_{3}\right): \delta 11.15(\mathrm{~s}, 2 \mathrm{H}, \mathrm{OH}), 9.87(\mathrm{~s}, 2 \mathrm{H}, \mathrm{CHO}), 7.74(\mathrm{~s}$, $2 \mathrm{H}, \mathrm{ArH}), 7.66\left(\mathrm{dd}, 2 \mathrm{H}, \mathrm{ArH},{ }^{3} J_{\mathrm{H}-\mathrm{H}}=5.7 \mathrm{~Hz},{ }^{4} J_{\mathrm{H}-\mathrm{H}}=2.1 \mathrm{~Hz}\right)$, $7.12\left(\mathrm{~s}, 2 \mathrm{H}\right.$, thiophene), $6.98\left(\mathrm{~d}, 2 \mathrm{H}, \mathrm{ArH},{ }^{3} J_{\mathrm{H}-\mathrm{H}}=8.7 \mathrm{~Hz}\right) \cdot{ }^{13} \mathrm{C}$ NMR $\left(\mathrm{CDCl}_{3}\right): \delta 195.9(\mathrm{CHO}), 161.7,139.5,136.8,131.8,124.3$, 120.5, 118.2, 114.4 (Ph), $92.3(\mathrm{C} \equiv \mathrm{C}), 81.7(\mathrm{C} \equiv \mathrm{C})$. MS (FAB): $\mathrm{m} / \mathrm{z}$ $373.3\left(\mathrm{M}^{+}+1\right)$. Anal. Calc. for $\mathrm{C}_{22} \mathrm{H}_{12} \mathrm{O}_{4} \mathrm{~S}: \mathrm{C}, 70.96 ; \mathrm{H}, 3.25 ; \mathrm{S}$, 8.61. Found: C, $71.05 ; \mathrm{H}, 3.33$; S, $8.71 \%$.

Compound 3. The mixture of 5-ethynylsalicylaldehyde (100 mg, $0.68 \mathrm{mmol})$, 1,4-bis-dodecyloxy-2,5-diiodobenzene (159 mg, $0.228 \mathrm{mmol}), \mathrm{Pd}\left(\mathrm{PPh}_{3}\right)_{2} \mathrm{Cl}_{2}(24 \mathrm{mg}, 0.034 \mathrm{mmol})$ and $\mathrm{CuI}$ ( $6 \mathrm{mg}, 0.032 \mathrm{mmol}$ ) were dissolved in THF, followed by addition of $\mathrm{Et}_{3} \mathrm{~N}(20 \mathrm{~mL})$. The reaction mixture was heated to $70{ }^{\circ} \mathrm{C}$ overnight. After cooling to room temperature, the solvent was removed by a rotary evaporator. The residue was purified by flash chromatography on silica gel (EA-hexanes, $1: 3$ ), then EA as eluent on a short plug of silica gel. The solvent was removed and then washed by methanol to yield 3 as a brown powder $(134 \mathrm{mg}, 80 \%)$. Spectroscopic data of 3: ${ }^{1} \mathrm{H}$ NMR $\left(\mathrm{CDCl}_{3}\right): \delta 11.11(\mathrm{~s}, 2 \mathrm{H}, \mathrm{OH})$, $9.86(\mathrm{~s}, 2 \mathrm{H}, \mathrm{CHO}), 7.73(\mathrm{~s}, 2 \mathrm{H}, \mathrm{ArH}), 7.65\left(\mathrm{dd}, 2 \mathrm{H}, \mathrm{ArH},{ }^{3} J_{\mathrm{H}-\mathrm{H}}=\right.$ $\left.6.6 \mathrm{~Hz},{ }^{4} J_{\mathrm{H}-\mathrm{H}}=1.6 \mathrm{~Hz}\right), 6.98(\mathrm{~s}, 2 \mathrm{H}, \mathrm{ArH}), 6.97(\mathrm{~d}, 2 \mathrm{H}, \mathrm{ArH}$, $\left.{ }^{3} J_{\mathrm{H}-\mathrm{H}}=6.21 \mathrm{~Hz}\right), 4.01\left(\mathrm{t}, 4 \mathrm{H}, \mathrm{OCH}_{2},{ }^{3} J_{\mathrm{H}-\mathrm{H}}=6.5 \mathrm{~Hz}\right), 1.87-1.78(\mathrm{~m}$, $\left.4 \mathrm{H}, \mathrm{CH}_{2}\right), 1.56-1.46\left(\mathrm{~m}, 4 \mathrm{H}, \mathrm{CH}_{2}\right), 1.37-1.21\left(\mathrm{~m}, 32 \mathrm{H}, \mathrm{CH}_{2}\right), 0.85$ $\left(\mathrm{t}, 6 \mathrm{H}, \mathrm{CH}_{3},{ }^{3} \mathrm{~J}_{\mathrm{H}-\mathrm{H}}=6.9 \mathrm{~Hz}\right) \cdot{ }^{13} \mathrm{C} \mathrm{NMR}\left(\mathrm{CDCl}_{3}\right): \delta 196.0(\mathrm{CHO})$, $161.4,153.6,139.7,136.7,1250.5,118.1,116.8,115.4,113.7(\mathrm{Ph})$, 93.0, 85.4 (C $\equiv \mathrm{C}), 69.6\left(\mathrm{OCH}_{2}\right), 31.8,29.6,29.6,29.6,29.4,29.3$, 26.0, 22.6 $\left(\mathrm{CH}_{2}\right), 14.0\left(\mathrm{CH}_{3}\right)$. MS (FAB): $m / z 735.0\left(\mathrm{M}^{+}+1\right)$. Anal. Calc. for $\mathrm{C}_{48} \mathrm{H}_{62} \mathrm{O}_{6}: \mathrm{C}, 78.44 ; \mathrm{H}, 8.50$. Found: C, 78.56; H, 8.44\%.

Monoimine 6b. Compound 5b (200 mg, $0.42 \mathrm{mmol})$ was treated with 2,3-diaminopyridine (364 $\mathrm{mg}, 3.34 \mathrm{mmol}$ ) and the mixture in THF $(20 \mathrm{ml})$ was stirred at $60{ }^{\circ} \mathrm{C}$. Then $\mathrm{MeOH}$ was added slowly into the resulting solution. The mixture was stirred at reflux temperature for $18 \mathrm{hr}$. Then the solvent was removed under vacuum. The residue was washed with methanol and precipitate was collected by filtration. Yellow organic monoimine $6 \mathbf{b}(107 \mathrm{mg}$, $45 \%$ ) was obtained by extracting from the precipitate by using three lots of $10 \mathrm{~mL}$ of $\mathrm{CH}_{2} \mathrm{Cl}_{2}$. Spectroscopic data of $6 \mathbf{b}$ : ${ }^{1} \mathrm{H}$ NMR $\left(\mathrm{CDCl}_{3}\right): \delta 12.17(\mathrm{~s}, 1 \mathrm{H}, \mathrm{OH}), 8.61(\mathrm{~s}, 1 \mathrm{H}, \mathrm{N}=\mathrm{CH}), 7.87(\mathrm{dd}, 1 \mathrm{H}$, $\left.\mathrm{PyrH},{ }^{3} J_{\mathrm{H}-\mathrm{H}}=6.0 \mathrm{~Hz},{ }^{4} J_{\mathrm{H}-\mathrm{H}}=1.7 \mathrm{~Hz}\right), 7.69-7.30(\mathrm{~m}, 10 \mathrm{H}, \operatorname{ArH})$, $7.04\left(\mathrm{~d}, 1 \mathrm{H}, \operatorname{ArH},{ }^{3} J_{\mathrm{H}-\mathrm{H}}=11.1 \mathrm{~Hz}\right), 6.81\left(\mathrm{dd}, 1 \mathrm{H}, \mathrm{ArH},{ }^{3} J_{\mathrm{H}-\mathrm{H}}=\right.$ $\left.7.2 \mathrm{~Hz},{ }^{4} J_{\mathrm{H}-\mathrm{H}}=2.7 \mathrm{~Hz}\right), 6.13\left(\mathrm{~s}, 2 \mathrm{H}, \mathrm{NH}_{2}\right) .{ }^{13} \mathrm{C} \mathrm{NMR}\left(\mathrm{CDCl}_{3}\right): \delta$ $163.7(\mathrm{Ph}), 160.7(\mathrm{C}=\mathrm{N}), 152.7,150.9,141.6,140.3,139.7,137.0$, 136.7, 135.6, 130.9, 130.4, 127.5, 126.8, 125.9, 122.8, 121.1, 119.9, 119.6, 119.0, 118.1, 117.8, 114.9, $114.2(\mathrm{Ph}), 89.7(\mathrm{C} \equiv \mathrm{C}), 88.0$ $(\mathrm{C} \equiv \mathrm{C}), 55.1,40.3,31.4,29.6,23.6,22.5,13.9\left(\mathrm{CH}_{3}\right) . \mathrm{MS}(\mathrm{FAB})$ : 
$m / z 570.7\left(\mathrm{M}^{+}+1\right)$. Anal. Calc. for $\mathrm{C}_{39} \mathrm{H}_{43} \mathrm{~N}_{3} \mathrm{O}: \mathrm{C}, 82.21 ; \mathrm{H}, 7.61$; N, 7.37. Found: C, 82.32; H, 7.68; N, 7.44.

\section{Synthesis of dinuclear $\mathrm{Zn}$ (II)-salophen complexes of type 1}

Complex 7a. Under a nitrogen atmosphere, the mixture of compound 1 (20 mg, $0.075 \mathrm{mmol})$ and $\mathrm{Zn}(\mathrm{OAc})_{2} \cdot 2 \mathrm{H}_{2} \mathrm{O}(66 \mathrm{mg}$, $0.30 \mathrm{mmol})$ dissolved in THF-MeOH $(30 \mathrm{~mL}-5 \mathrm{~mL})$ was stirred at $60{ }^{\circ} \mathrm{C}$ for $30 \mathrm{~min}$. Subsequently, $6 \mathbf{a}$ ( $48 \mathrm{mg}, 0.15 \mathrm{mmol}$ ) dissolved in $\mathrm{THF}(10 \mathrm{~mL})$ was added to this mixture slowly, and the reaction mixture was heated at $60{ }^{\circ} \mathrm{C}$ for 2 day. After cooling to room temperature, the solvent was removed under vacuum and the residue was washed with methanol, hexanes and ether. The precipitate was collected by filtration to yield 7a as orange powder in $70 \%$ yield $(52 \mathrm{mg})$. Spectroscopic data of 7a: ${ }^{1} \mathrm{H}$ NMR $\left(d_{6}-\right.$ DMSO): $\delta 9.45$ (s, 2H, N=CH), $9.13(\mathrm{~s}, 2 \mathrm{H}, \mathrm{N}=\mathrm{CH}), 8.44$ (br, $2 \mathrm{H}$, PyrH), 8.33 (br, 2H, PyrH), 7.70-7.31 (m, 14H, ArH), 7.09 (br, $2 \mathrm{H}$, thiophene), 6.75 (br, $4 \mathrm{H}, \mathrm{ArH}) .{ }^{13} \mathrm{C} \mathrm{NMR}\left(d_{6}\right.$-DMSO): $\delta 175.4$ $(\mathrm{Ph}), 174.9(\mathrm{Ph}), 164.7(\mathrm{C}=\mathrm{N}), 164.4(\mathrm{C}=\mathrm{N}), 147.7,141.2,139.1$, 138.2, 135.9, 132.0, 128.2, 127.8, 125.7, 125.1, 120.7, 120.4, 109.8, 107.9, $95.2(\mathrm{C} \equiv \mathrm{C}), 88.7(\mathrm{C} \equiv \mathrm{C}), 81.3(\mathrm{C} \equiv \mathrm{C})$. MALDI-TOF-MS: $m / z 996.38\left(\mathrm{M}^{+}+1\right)$. Anal. Calc. for $\mathrm{C}_{52} \mathrm{H}_{28} \mathrm{~N}_{6} \mathrm{O}_{4} \mathrm{~S}_{2} \mathrm{Zn}_{2} \cdot 6 \mathrm{H}_{2} \mathrm{O}: \mathrm{C}$, 56.58; H, 3.65; N, 7.61. Found: C, 56.69; H, 3.68; N, 7.53\%.

Complex 7b. Complex $\mathbf{7 b}$ as an red powder was similarly prepared by the same procedure as that of complex $7 \mathbf{a}$ with $63 \%$ yield. Spectroscopic data of $7 \mathbf{b}:{ }^{1} \mathrm{H}$ NMR $\left(d_{8}\right.$-THF): $\delta 9.61$ (s, $2 \mathrm{H}, \mathrm{N}=\mathrm{CH}), 9.02(\mathrm{~s}, 2 \mathrm{H}, \mathrm{N}=\mathrm{CH}), 8.40\left(\mathrm{~d}, 2 \mathrm{H}, \mathrm{PyrH},{ }^{3} J_{\mathrm{H}-\mathrm{H}}=\right.$ $3.4 \mathrm{~Hz}), 8.22\left(\mathrm{~d}, 2 \mathrm{H}, \mathrm{PyrH},{ }^{3} J_{\mathrm{H}-\mathrm{H}}=7.4 \mathrm{~Hz}\right), 7.73-7.69(\mathrm{~m}, 4 \mathrm{H}$, ArH), 7.58 (s, 4H, ArH), 7.49 (s, 2H, ArH), 7.43-7.35 (m, 10H, ArH), 7.32-7.26 (m, 4H, ArH), $6.82\left(\mathrm{~d}, 4 \mathrm{H}, \mathrm{ArH},{ }^{3} J_{\mathrm{H}-\mathrm{H}}=9.4 \mathrm{~Hz}\right)$, 2.57 (br, 8H, $\mathrm{CH}_{2}$ ), 1.73-1.05 (m, 24H, $\left.\mathrm{CH}_{2}\right), 0.77$ (t, 12H, $\mathrm{CH}_{3}$, $\left.{ }^{3} J_{\mathrm{H}-\mathrm{H}}=7.2 \mathrm{~Hz}\right), 0.62\left(\mathrm{~m}, 8 \mathrm{H}, \mathrm{CH}_{2}\right) \cdot{ }^{13} \mathrm{C} \mathrm{NMR}\left(d_{6}\right.$-DMSO): $\delta$ $175.5(\mathrm{Ph}), 174.9(\mathrm{Ph}), 164.8(\mathrm{C}=\mathrm{N}), 164.5(\mathrm{C}=\mathrm{N}), 151.8,151.6$, 151.4, 150.1, 149.8, 149.6, 147.3, 141.5, 140.1, 138.2, 138.1, 135.9, $130.9,128.1,127.7,126.1,125.6,125.4,124.9,124.3,124.1,123.8$, $123.6,120.7,120.5,120.4,120.1,96.1(\mathrm{C} \equiv \mathrm{C}), 88.8(\mathrm{C} \equiv \mathrm{C}), 81.8$ $(\mathrm{C} \equiv \mathrm{C}), 55.8,41.1,32.2,30.5,24.6,23.4,14.2\left(\mathrm{CH}_{3}\right)$. Anal. Calc. for $\mathrm{C}_{94} \mathrm{H}_{88} \mathrm{~N}_{6} \mathrm{O}_{4} \mathrm{Zn}_{2} \cdot 6 \mathrm{H}_{2} \mathrm{O}$ : C, 70.36; $\mathrm{H}, 6.28 ; \mathrm{N}, 5.24$. Found: $\mathrm{C}$, $70.51 ; \mathrm{H}, 6.41 ; \mathrm{N}, 5.13 \%$.

Complex 8a. Complex 8a as a brown powder was similarly prepared by the same procedure as that of complex $7 \mathbf{a}$ with $66 \%$ yield. Spectroscopic data of 8a: ${ }^{1} \mathrm{H}$ NMR $\left(d_{8}-\mathrm{THF}\right): \delta 9.58(\mathrm{~s}, 2 \mathrm{H}$, $\mathrm{N}=\mathrm{CH}), 8.99$ (s, 2H, N=CH), 8.53 (s, 2H, PyrH), 8.21 (d, 2H, PyrH, $\left.{ }^{3} J_{\mathrm{H}-\mathrm{H}}=7.9 \mathrm{~Hz}\right), 7.64$ (s, 2H, ArH), 7.55 (s, 2H, ArH), 7.34 (m, 10H, ArH), 7.17 (s, 4H, thiophene), 6.98 (s, 2H, ArH). ${ }^{13} \mathrm{C}$ NMR ( $d_{5}$-Pyridine): $\delta 175.7(\mathrm{Ph}), 174.9(\mathrm{Ph}), 164.7(\mathrm{C}=\mathrm{N}), 164.4$ $(\mathrm{C}=\mathrm{N}), 151.0,150.6,147.7,142.1,141.1,138.6,138.3,135.7,132.0$, 128.3, 127.8, 127.8, 125.8, 125.7, 125.2, 125.2, 125.1, 120.7, 120.4, 108.1, 107.9, $95.7(\mathrm{C} \equiv \mathrm{C}), 95.2(\mathrm{C} \equiv \mathrm{C}), 81.4(\mathrm{C} \equiv \mathrm{C}), 81.3(\mathrm{C} \equiv \mathrm{C})$. Anal. Calc. for $\mathrm{C}_{58} \mathrm{H}_{30} \mathrm{~N}_{6} \mathrm{O}_{4} \mathrm{~S}_{3} \mathrm{Zn}_{2} \cdot 6 \mathrm{H}_{2} \mathrm{O}: \mathrm{C}, 57.58 ; \mathrm{H}, 3.50 ; \mathrm{N}, 6.95$; S, 7.95. Found: C, 57.76; H, 3.58; N, 7.05; S, 8.05\%.

Complex 8b. Complex $\mathbf{8 b}$ as an orange powder was similarly prepared by the same procedure as that of complex 7a with $62 \%$ yield. Spectroscopic data of $\mathbf{8 b}:{ }^{1} \mathrm{H}$ NMR $\left(d_{8}-\mathrm{THF}\right): \delta 9.57(\mathrm{~s}, 2 \mathrm{H}$, $\mathrm{N}=\mathrm{CH}), 9.00(\mathrm{~s}, 2 \mathrm{H}, \mathrm{N}=\mathrm{CH}), 8.37\left(\mathrm{~d}, 2 \mathrm{H}, \mathrm{PyrH},{ }^{3} J_{\mathrm{H}-\mathrm{H}}=3.4 \mathrm{~Hz}\right)$, $8.20\left(\mathrm{~d}, 2 \mathrm{H}, \mathrm{PyrH},{ }^{3} J_{\mathrm{H}-\mathrm{H}}=8.3 \mathrm{~Hz}\right), 7.71-7.69(\mathrm{~m}, 4 \mathrm{H}, \mathrm{ArH}), 7.65$ (s, 2H, ArH), 7.58 (s, 2H, ArH), 7.48 (s, 2H, ArH), 7.43-7.35 (m, 10H, ArH), 7.32-7.26 (m, 4H, ArH), 7.08 (s, 2H, thiophene), $6.79\left(\mathrm{~d}, 4 \mathrm{H}, \mathrm{ArH},{ }^{3} J_{\mathrm{H}-\mathrm{H}}=8.7 \mathrm{~Hz}\right), 2.03\left(\mathrm{t}, 8 \mathrm{H}, \mathrm{CH}_{2},{ }^{3} J_{\mathrm{H}-\mathrm{H}}=\right.$ $7.9 \mathrm{~Hz}), 1.12-1.05\left(\mathrm{~m}, 24 \mathrm{H}, \mathrm{CH}_{2}\right), 0.76\left(\mathrm{t}, 12 \mathrm{H}, \mathrm{CH}_{3},{ }^{3} J_{\mathrm{H}-\mathrm{H}}=\right.$ $7.1 \mathrm{~Hz}), 0.61\left(\mathrm{~m}, 8 \mathrm{H}, \mathrm{CH}_{2}\right) \cdot{ }^{13} \mathrm{C} \mathrm{NMR}\left(d_{8}-\mathrm{THF}\right): \delta 175.8(\mathrm{Ph})$, $174.8(\mathrm{Ph}), 164.4(\mathrm{C}=\mathrm{N}), 164.3(\mathrm{C}=\mathrm{N}), 151.6,151.5,151.3,150.1$, 149.9, 149.7, 147.5, 141.7, 140.4, 138.2, 138.1, 135.9, 131.6, 130.9, $128.1,127.7,126.2,125.6,125.4,124.9,124.5,124.3,123.8,123.7$, 123.6, 120.7, 120.5, 120.4, 120.3, $95.7(\mathrm{C} \equiv \mathrm{C}), 91.6(\mathrm{C} \equiv \mathrm{C}), 88.6$ $(\mathrm{C} \equiv \mathrm{C}), 80.5(\mathrm{C} \equiv \mathrm{C}), 55.9,41.3,32.5,30.7,24.7,23.5,14.3\left(\mathrm{CH}_{3}\right)$. Anal. Calc. for $\mathrm{C}_{100} \mathrm{H}_{90} \mathrm{~N}_{6} \mathrm{O}_{4} \mathrm{SZn}_{2} \cdot 6 \mathrm{H}_{2} \mathrm{O}: \mathrm{C}, 70.21 ; \mathrm{H}, 6.01$; N, 4.91; S, 1.87. Found: C, 70.36; H, 6.06; N, 4.81; S, 1.93\%.

Complex 9a. Complex 9a as an orange solid was similarly prepared by the same procedure as that of complex 7a with $65 \%$ yield. Spectroscopic data of 9a: ${ }^{1} \mathrm{H}$ NMR $\left(d_{6}\right.$-DMSO): $\delta 9.43$ (s, $2 \mathrm{H}, \mathrm{N}=\mathrm{CH}), 9.13(\mathrm{~s}, 2 \mathrm{H}, \mathrm{N}=\mathrm{CH}), 8.43\left(\mathrm{~d}, 2 \mathrm{H}, \mathrm{PyrH},{ }^{3} J_{\mathrm{H}-\mathrm{H}}=\right.$ $3.45 \mathrm{~Hz}), 8.33\left(\mathrm{~d}, 2 \mathrm{H}, \mathrm{PyrH},{ }^{3} J_{\mathrm{H}-\mathrm{H}}=7.9 \mathrm{~Hz}\right), 7.71(\mathrm{~s}, 2 \mathrm{H}, \mathrm{ArH})$, $7.66(\mathrm{~s}, 2 \mathrm{H}, \mathrm{ArH}), 7.58\left(\mathrm{~d}, 2 \mathrm{H}\right.$, thiophene, $\left.{ }^{3} J_{\mathrm{H}-\mathrm{H}}=5.2 \mathrm{~Hz}\right), 7.50(\mathrm{~m}$, $2 \mathrm{H}, \mathrm{PyrH}), 7.39(\mathrm{~m}, 4 \mathrm{H}, \mathrm{ArH}), 7.31\left(\mathrm{~d}, 2 \mathrm{H}\right.$, thiophene, ${ }^{3} J_{\mathrm{H}-\mathrm{H}}=$ $3.3 \mathrm{~Hz}), 7.09\left(\mathrm{t}, 2 \mathrm{H}\right.$, thiophene, $\left.{ }^{3} J_{\mathrm{H}-\mathrm{H}}=3.9 \mathrm{~Hz}\right), 7.04(\mathrm{~s}, 2 \mathrm{H}$, $\mathrm{CH}), 6.78\left(\mathrm{~d}, 2 \mathrm{H}, \operatorname{ArH},{ }^{3} J_{\mathrm{H}-\mathrm{H}}=7.9 \mathrm{~Hz}\right), 6.76(\mathrm{~d}, 2 \mathrm{H}, \mathrm{ArH}$, $\left.{ }^{3} J_{\mathrm{H}-\mathrm{H}}=7.2 \mathrm{~Hz}\right), 4.01\left(\mathrm{t}, 4 \mathrm{H}, \mathrm{OCH}_{2},{ }^{3} J_{\mathrm{H}-\mathrm{H}}=5.5 \mathrm{~Hz}\right), 1.80-1.74$ (m, 4H, $\mathrm{CH}_{2}$ ), $1.51\left(\mathrm{~m}, 4 \mathrm{H}, \mathrm{CH}_{3}\right), 1.36-1.11\left(\mathrm{~m}, 32 \mathrm{H}, \mathrm{CH}_{2}\right), 0.76$ $\left(\mathrm{t}, 6 \mathrm{H}, \mathrm{CH}_{3},{ }^{3} J_{\mathrm{H}-\mathrm{H}}=6.9 \mathrm{~Hz}\right) .{ }^{13} \mathrm{C} \mathrm{NMR}\left(d_{6}\right.$-DMSO): $\delta 173.1$ $(\mathrm{Ph}), 172.8(\mathrm{Ph}), 163.8(\mathrm{C}=\mathrm{N}), 162.9(\mathrm{C}=\mathrm{N}), 149.4,146.7,140.1$, 140.0, 137.6, 136.6, 134.2, 131.3, 127.7, 127.6, 124.9, 124.1, 123.3, 122.9, 119.6, 119.0, 105.7, 93.7, $79.9(\mathrm{C} \equiv \mathrm{C}), 79.2(\mathrm{C} \equiv \mathrm{C}), 78.9$ $(\mathrm{C} \equiv \mathrm{C}), 78.6(\mathrm{C} \equiv \mathrm{C}), 67.5\left(\mathrm{OCH}_{2}\right), 29.6,29.5,23.9,29.1,28.9$, 28.8, 26.4, 25.1, 22.7, $19.3\left(\mathrm{CH}_{2}\right), 14.1\left(\mathrm{CH}_{3}\right)$. Anal. Calc. for $\mathrm{C}_{84} \mathrm{H}_{80} \mathrm{~N}_{6} \mathrm{O}_{6} \mathrm{~S}_{2} \mathrm{Zn}_{2} \cdot 6 \mathrm{H}_{2} \mathrm{O}: \mathrm{C}, 64.16 ; \mathrm{H}, 5.90 ; \mathrm{N}, 5.34 ; \mathrm{S}, 4.08$. Found: C, 64.26; H, 5.92; N, 5.19, S, 4.16\%.

Complex 9b. Complex 9b as an orange solid was similarly prepared by the same procedure as that of complex $7 \mathbf{a}$ with $67 \%$ yield. Spectroscopic data of $9 \mathbf{b}:{ }^{1} \mathrm{H}$ NMR $\left(d_{8}-\mathrm{THF}\right): \delta 9.62(\mathrm{~s}, 2 \mathrm{H}$, $\mathrm{N}=\mathrm{CH}), 9.02(\mathrm{~s}, 2 \mathrm{H}, \mathrm{N}=\mathrm{CH}), 8.40\left(\mathrm{~d}, 2 \mathrm{H}, \mathrm{PyrH},{ }^{3} J_{\mathrm{H}-\mathrm{H}}=3.40 \mathrm{~Hz}\right)$, $8.23\left(\mathrm{~d}, 2 \mathrm{H}, \operatorname{PyrH},{ }^{3} J_{\mathrm{H}-\mathrm{H}}=8.0 \mathrm{~Hz}\right), 7.72-7.69(\mathrm{~m}, 4 \mathrm{H}, \mathrm{ArH}), 7.62$ (s, 2H, ArH), 7.59 (s, 2H, ArH), 7.49 (s, 2H, ArH), 7.43-7.37 (m, 10H, ArH), 7.32-7.28 (m, 4H, ArH), 7.00 (s, 2H, CH), 6.85 (d, 4H, $\left.\mathrm{ArH},{ }^{3} J_{\mathrm{H}-\mathrm{H}}=5.04 \mathrm{~Hz}\right), 4.05\left(\mathrm{t}, 4 \mathrm{H}, \mathrm{OCH}_{2},{ }^{3} J_{\mathrm{H}-\mathrm{H}}=6.3 \mathrm{~Hz}\right), 2.03(\mathrm{t}$, $\left.8 \mathrm{H}, \mathrm{CH}_{2},{ }^{3} J_{\mathrm{H}-\mathrm{H}}=8.0 \mathrm{~Hz}\right), 1.95\left(\mathrm{~m}, 4 \mathrm{H}, \mathrm{CH}_{2}\right), 1.62\left(\mathrm{~m}, 4 \mathrm{H}, \mathrm{CH}_{2}\right)$, $1.36-1.06\left(\mathrm{~m}, 32 \mathrm{H}, \mathrm{CH}_{2}\right), 0.87\left(\mathrm{t}, 6 \mathrm{H}, \mathrm{CH}_{3},{ }^{3} J_{\mathrm{H}-\mathrm{H}}=7.0 \mathrm{~Hz}\right), 0.77(\mathrm{t}$, $\left.12 \mathrm{H}, \mathrm{CH}_{3},{ }^{3} J_{\mathrm{H}-\mathrm{H}}=7.2 \mathrm{~Hz}\right), 0.62\left(\mathrm{~m}, 8 \mathrm{H}, \mathrm{CH}_{2}\right) .{ }^{13} \mathrm{C} \mathrm{NMR}\left(d_{8}-\mathrm{THF}\right)$ : $\delta 173.1(\mathrm{Ph}), 172.8(\mathrm{Ph}), 164.0(\mathrm{C}=\mathrm{N}), 163.7(\mathrm{C}=\mathrm{N}), 154.5,151.7$, 151.6, 151.5, 147.4, 141.7, 141.7, 141.2, 140.5, 138.6, 138.0, 135.5, $130.9,128.1,127.7,126.2,125.4,125.4,124.5,123.8,123.6,123.5$, $120.7,120.5,120.4,120.1,117.5,109.4,108.8,95.9(\mathrm{C} \equiv \mathrm{C}), 91.1$ $(\mathrm{C} \equiv \mathrm{C}), 88.6(\mathrm{C} \equiv \mathrm{C}), 84.8(\mathrm{C} \equiv \mathrm{C}), 70.2\left(\mathrm{OCH}_{2}\right), 55.9,49.9,41.3$, $32.9,32.5,30.8,30.7,30.6,30.5,30.3,27.2,25.8,25.3,23.5,23.4$, $14.5\left(\mathrm{CH}_{2}\right), 14.3\left(\mathrm{CH}_{3}\right)$. Anal. Calc. for $\mathrm{C}_{126} \mathrm{H}_{140} \mathrm{~N}_{6} \mathrm{O}_{6} \mathrm{Zn}_{2} \cdot 6 \mathrm{H}_{2} \mathrm{O}$ : C, 72.99; H, 7.39; N, 4.05. Found: C, 73.11; H, 7.26; N, 4.11\%.

Complex 9c. Complex 9c as a dark red powder was similarly prepared by the same procedure as that of complex 7a with $63 \%$ yield. Spectroscopic data of 9c: ${ }^{1} \mathrm{H}$ NMR $\left(d_{8}\right.$-THF): $\delta 9.60$ (s, $2 \mathrm{H}, \mathrm{N}=\mathrm{CH}), 8.95(\mathrm{~s}, 2 \mathrm{H}, \mathrm{N}=\mathrm{CH}), 8.37\left(\mathrm{~d}, 2 \mathrm{H}, \mathrm{PyrH},{ }^{3} J_{\mathrm{H}-\mathrm{H}}=\right.$ $4.4 \mathrm{~Hz}), 8.20\left(\mathrm{~d}, 2 \mathrm{H}, \mathrm{PyrH},{ }^{3} J_{\mathrm{H}-\mathrm{H}}=8.9 \mathrm{~Hz}\right), 7.60(\mathrm{~s}, 2 \mathrm{H}, \mathrm{ArH})$, $7.38-7.33(\mathrm{~m}, 6 \mathrm{H}, \mathrm{ArH}), 7.20\left(\mathrm{~d}, 2 \mathrm{H}, \mathrm{PyrH},{ }^{3} J_{\mathrm{H}-\mathrm{H}}=8.7 \mathrm{~Hz}\right), 6.99$ $(\mathrm{s}, 2 \mathrm{H}, \mathrm{ArH}), 6.80\left(\mathrm{~d}, 2 \mathrm{H}, \mathrm{ArH},{ }^{3} J_{\mathrm{H}-\mathrm{H}}=8.9 \mathrm{~Hz}\right), 6.74(\mathrm{~d}, 2 \mathrm{H}, \mathrm{ArH}$, $\left.{ }^{3} J_{\mathrm{H}-\mathrm{H}}=8.7 \mathrm{~Hz}\right), 4.05\left(\mathrm{t}, 4 \mathrm{H}, \mathrm{OCH}_{2},{ }^{3} J_{\mathrm{H}-\mathrm{H}}=5.8 \mathrm{~Hz}\right), 2.37(\mathrm{t}, 4 \mathrm{H}$, $\left.\mathrm{C} \equiv \mathrm{CCH}_{2},{ }^{3} J_{\mathrm{H}-\mathrm{H}}=7.0 \mathrm{~Hz}\right), 1.88-1.26\left(\mathrm{~m}, 72 \mathrm{H}, \mathrm{CH}_{2}\right), 0.89-0.85$ 
$\left(\mathrm{m}, 12 \mathrm{H}, \mathrm{CH}_{3}\right) .{ }^{13} \mathrm{C}$ NMR $\left(d_{5}\right.$-Pyridine): $\delta 175.5(\mathrm{Ph}), 174.3(\mathrm{Ph})$, $164.6(\mathrm{C}=\mathrm{N}), 164.4(\mathrm{C}=\mathrm{N}), 154.5,151.0,150.6,147.5,141.69$, $140.5,139.0,138.9,135.4,125.8,125.4,125.1,123.5,117.8,115.3$, 109.8, 109.2, $96.9(\mathrm{C} \equiv \mathrm{C}), 88.3(\mathrm{C} \equiv \mathrm{C}), 85.6(\mathrm{C} \equiv \mathrm{C}), 82.0(\mathrm{C} \equiv \mathrm{C})$, $70.2\left(\mathrm{OCH}_{2}\right), 32.5\left(\mathrm{C} \equiv \mathrm{CCH}_{2}\right), 32.5,30.8,30.7,30.6,30.5,30.4$, 30.3, 30.2, 30.0, 29.9, 29.7, 27.2, 27.0, 25.8, 25.3, 23.5, 23.4, 20.2, $14.5\left(\mathrm{CH}_{2}\right), 14.3\left(\mathrm{CH}_{3}\right)$. FAB-MS: $m / z 1579.9\left(\mathrm{M}^{+}\right)$. Anal. Calc. for $\mathrm{C}_{96} \mathrm{H}_{116} \mathrm{~N}_{6} \mathrm{O}_{6} \mathrm{Zn}_{2} \cdot 6 \mathrm{H}_{2} \mathrm{O}: \mathrm{C}, 68.27 ; \mathrm{H}, 7.64 ; \mathrm{N}, 4.98$. Found: $\mathrm{C}$, $68.45 ; \mathrm{H}, 7.53 ; \mathrm{N}, 4.89 \%$.

Complex 10a. Complex 10a as an orange powder was similarly prepared by the same procedure as that of complex 7a with $60 \%$ yield. Spectroscopic data of 10a: ${ }^{1} \mathrm{H}$ NMR ( $d_{6}$-DMSO): $\delta 9.40$ (s, $2 \mathrm{H}, \mathrm{N}=\mathrm{CH}), 9.11(\mathrm{~s}, 2 \mathrm{H}, \mathrm{N}=\mathrm{CH}), 8.40\left(\mathrm{~d}, 2 \mathrm{H}, \mathrm{PyrH},{ }^{3} J_{\mathrm{H}-\mathrm{H}}=\right.$ $1.2 \mathrm{~Hz}), 8.29$ (d, 2H, PyrH, $\left.{ }^{3} J_{\mathrm{H}-\mathrm{H}}=7.2 \mathrm{~Hz}\right), 7.69$ (d, 2H, ArH, $\left.{ }^{4} J_{\mathrm{H}-\mathrm{H}}=2.3 \mathrm{~Hz}\right), 7.58\left(\mathrm{~d}, 2 \mathrm{H}, \mathrm{ArH},{ }^{4} J_{\mathrm{H}-\mathrm{H}}=4.1 \mathrm{~Hz}\right), 7.43(\mathrm{dd}, 2 \mathrm{H}$, thiophene, $\left.{ }^{3} J_{\mathrm{H}-\mathrm{H}}=4.9 \mathrm{~Hz},{ }^{4} J_{\mathrm{H}-\mathrm{H}}=3.5 \mathrm{~Hz}\right), 7.37(\mathrm{dd}, 2 \mathrm{H}, \mathrm{ArH}$, $\left.{ }^{3} J_{\mathrm{H}-\mathrm{H}}=6.5 \mathrm{~Hz},{ }^{4} J_{\mathrm{H}-\mathrm{H}}=2.4 \mathrm{~Hz}\right), 7.31-7.30(\mathrm{~m}, 4 \mathrm{H}, \mathrm{ArH}), 7.22$ $\left(\mathrm{d}, 2 \mathrm{H}, \mathrm{ArH},{ }^{3} J_{\mathrm{H}-\mathrm{H}}=8.8 \mathrm{~Hz}\right), 7.08\left(\mathrm{dd}, 2 \mathrm{H}\right.$, thiophene, ${ }^{3} J_{\mathrm{H}-\mathrm{H}}=$ $3.7 \mathrm{~Hz}), 6.74\left(\mathrm{~d}, 2 \mathrm{H}, \mathrm{ArH},{ }^{3} J_{\mathrm{H}-\mathrm{H}}=8.9 \mathrm{~Hz}\right), 6.70(\mathrm{~d}, 2 \mathrm{H}, \mathrm{ArH}$, $\left.{ }^{3} J_{\mathrm{H}-\mathrm{H}}=8.7 \mathrm{H}\right), 3.70(\mathrm{~s}, 2 \mathrm{H}, \mathrm{CH}) .{ }^{13} \mathrm{C} \mathrm{NMR}\left(d_{6}\right.$-DMSO): $\delta 172.7$ $(\mathrm{Ph}), 172.3(\mathrm{Ph}), 163.6(\mathrm{C}=\mathrm{N}), 162.9(\mathrm{C}=\mathrm{N}), 149.8,146.6,140.0$, $136.6,136.5,135.6,133.9,131.2,127.7,127.6,126.5,124.6,124.2$,

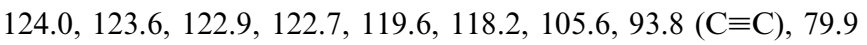
$(\mathrm{C} \equiv \mathrm{C}), 41.2\left(\mathrm{CH}_{2}\right)$. Anal. Calc. for $\mathrm{C}_{51} \mathrm{H}_{30} \mathrm{~N}_{6} \mathrm{O}_{4} \mathrm{~S}_{2} \mathrm{Zn}_{2} \cdot 6 \mathrm{H}_{2} \mathrm{O}: \mathrm{C}$, 56.00; H, 3.87; N, 7.68; S, 5.86. Found: C, 56.18; H, 3.82; N, 7.57; $\mathrm{S}, 5.98 \%$.

Complex 10c. Complex 10c as dark red solid was similarly prepared by the same procedure as that of complex 7a with $63 \%$ yield. Spectroscopic data of 10c: ${ }^{1} \mathrm{H}$ NMR $\left(d_{8}-\mathrm{THF}\right): \delta 9.53(\mathrm{~s}$, $2 \mathrm{H}, \mathrm{N}=\mathrm{CH}$ ), 8.93 (s, 2H, N=CH), 8.33 (s, 2H, PyrH), 8.16 (s, 2H, PyrH), 7.42 (s, 2H, ArH), 7.35-7.14 (m, 8H, ArH), 6.72 (d, 4H, $\left.\mathrm{ArH},{ }^{3} J_{\mathrm{H}-\mathrm{H}}=9.3 \mathrm{~Hz}\right), 3.84\left(\mathrm{~s}, 2 \mathrm{H}, \mathrm{CH}_{2}\right) .{ }^{13} \mathrm{C}$ NMR $\left(d_{5}\right.$-Pyridine): $\delta 174.8(\mathrm{Ph}), 174.3(\mathrm{Ph}), 165.0(\mathrm{C}=\mathrm{N}), 164.2(\mathrm{C}=\mathrm{N}), 151.5,151.1$, 147.4, 140.4, 138.7, 138.1, 136.9, 127.6, 125.5, 125.5, 125.4, 123.2, 120.5, 119.7, 109.7, 88.2 (C $\equiv \mathrm{C}), 82.1(\mathrm{C} \equiv \mathrm{C}), 40.5\left(\mathrm{CH}_{2}\right), 32.5$, 30.3, 30.0, 29.9, 29.9, 29.6, 23.4, $20.2\left(\mathrm{CH}_{2}\right), 14.7\left(\mathrm{CH}_{3}\right)$. FABMS: $m / z 1102.5\left(\mathrm{M}^{+}\right)$. Anal. Calc. for $\mathrm{C}_{63} \mathrm{H}_{66} \mathrm{~N}_{6} \mathrm{O}_{4} \mathrm{Zn}_{2} \cdot 6 \mathrm{H}_{2} \mathrm{O}: \mathrm{C}$, 62.53; H, 6.50; N, 6.94. Found: C, 62.71; H, 6.40; N, 6.99\%.

\section{Synthesis of dinuclear $\mathrm{Zn}$ (II)-salophen complexes of type 2}

Complex 11a. Under a nitrogen atmosphere, the compound 5 a $(60 \mathrm{mg}, 0.26 \mathrm{mmol})$ was first treated with $\mathrm{Zn}(\mathrm{OAc})_{2} \cdot 2 \mathrm{H}_{2} \mathrm{O}$ (144 mg, $0.66 \mathrm{mmol}$ ) and the mixture was stirred in THF$\mathrm{MeOH}(30 \mathrm{~mL} / 10 \mathrm{~mL})$ for $30 \mathrm{~min}$ at $60{ }^{\circ} \mathrm{C}$. Then the resulting solution of 1,2,4,5-tetraaminobenzene tetrahydrochloride $(19 \mathrm{mg}$, $0.067 \mathrm{mmol})$ in $\mathrm{MeOH}(10 \mathrm{~mL})$ was added slowly, and the mixture was stirred for 2 day at $60{ }^{\circ} \mathrm{C}$. Then the solvent of the mixture was removed by vacuum and residue was washed with methanol, hexanes and ether. The precipitate was collected by filtration. The red powder was identified as compound 11a in $65 \%$ yield (47 mg). Spectroscopic data of 11a: ${ }^{1} \mathrm{H}$ NMR ( $d_{6}$-DMSO): $\delta 9.13$ $(\mathrm{s}, 4 \mathrm{H}, \mathrm{N}=\mathrm{CH}), 8.29(\mathrm{~s}, 2 \mathrm{H}, \operatorname{ArH}), 7.72\left(\mathrm{~d}, 4 \mathrm{H}, \operatorname{ArH},{ }^{4} J_{\mathrm{H}-\mathrm{H}}=\right.$ $2.2 \mathrm{~Hz}), 7.57\left(\mathrm{~d}, 4 \mathrm{H}\right.$, thiophene, $\left.{ }^{3} J_{\mathrm{H}-\mathrm{H}}=4.1 \mathrm{~Hz}\right), 7.40(\mathrm{dd}, 4 \mathrm{H}$, $\left.\mathrm{ArH},{ }^{3} J_{\mathrm{H}-\mathrm{H}}=8.9 \mathrm{~Hz},{ }^{4} J_{\mathrm{H}-\mathrm{H}}=2.2 \mathrm{~Hz}\right), 7.32(\mathrm{dd}, 4 \mathrm{H}$, thiophene, $\left.{ }^{3} J_{\mathrm{H}-\mathrm{H}}=2.5 \mathrm{~Hz},{ }^{4} J_{\mathrm{H}-\mathrm{H}}=1.1 \mathrm{~Hz}\right), 7.09\left(\mathrm{dd}, 4 \mathrm{H}\right.$, thiophene, ${ }^{3} J_{\mathrm{H}-\mathrm{H}}=$ $\left.1.5 \mathrm{~Hz},{ }^{3} J_{\mathrm{H}-\mathrm{H}}=3.6 \mathrm{~Hz}\right), 6.76\left(\mathrm{~d}, 4 \mathrm{H}, \mathrm{ArH},{ }^{3} J_{\mathrm{H}-\mathrm{H}}=8.9 \mathrm{~Hz}\right) .{ }^{13} \mathrm{C}$
NMR $\left(d_{6}\right.$-DMSO): $\delta 162.3(\mathrm{Ph}), 152.5(\mathrm{C}=\mathrm{N}), 139.9,138.6,131.3$, 127.7, 127.6, 124.1, 123.9, 122.9, 119.6, 112.1, 93.6, $74.0(\mathrm{C} \equiv \mathrm{C})$, $67.6(\mathrm{C} \equiv \mathrm{C})$. MS (MALDI-TOF-MS): $m / z 1107.0\left(\mathrm{M}^{+}\right)$. Anal. Calc. for $\mathrm{C}_{58} \mathrm{H}_{30} \mathrm{~N}_{4} \mathrm{O}_{4} \mathrm{~S}_{4} \mathrm{Zn}_{2} \cdot 6 \mathrm{H}_{2} \mathrm{O}$ : C, 57.38; H, 3.49; N, 4.62; $\mathrm{S}$, 10.56. Found: C, 57.53; H, 3.48; N, 4.70; S, 10.68\%.

Complex 11b. Complex 11b as a red powder was similarly prepared by the synthetic procedure as that of complex 11a with $65 \%$ yield. Spectroscopic data of $11 \mathrm{~b}:{ }^{1} \mathrm{H}$ NMR $\left(d_{8}\right.$-THF): $\delta 9.18$ (s, 4H, N=CH), $8.35(\mathrm{~s}, 2 \mathrm{H}, \operatorname{ArH}), 7.70\left(\mathrm{~d}, 8 \mathrm{H}, \operatorname{ArH},{ }^{3} J_{\mathrm{H}-\mathrm{H}}=\right.$ $7.2 \mathrm{~Hz}), 7.65$ (s, 4H, ArH), 7.51 (s, 4H, ArH), 7.45-7.43 (m, 8H, $\mathrm{ArH}), 7.37\left(\mathrm{~d}, 4 \mathrm{H}, \mathrm{ArH},{ }^{3} J_{\mathrm{H}-\mathrm{H}}=5.5 \mathrm{~Hz}\right), 7.29(\mathrm{~m}, 8 \mathrm{H}, \mathrm{ArH}), 6.90$ $\left(\mathrm{d}, 4 \mathrm{H}, \mathrm{ArH},{ }^{3} J_{\mathrm{H}-\mathrm{H}}=8.8 \mathrm{~Hz}\right), 2.04\left(\mathrm{t}, 16 \mathrm{H}, \mathrm{CH}_{2},{ }^{3} J_{\mathrm{H}-\mathrm{H}}=8.1 \mathrm{~Hz}\right)$, 1.11-1.06 (m, 48H, $\left.\mathrm{CH}_{2}\right), 0.74\left(\mathrm{t}, 24 \mathrm{H}, \mathrm{CH}_{3},{ }^{3} J_{\mathrm{H}-\mathrm{H}}=7.1 \mathrm{~Hz}\right), 0.10$ $\left(\mathrm{m}, 16 \mathrm{H}, \mathrm{CH}_{2}\right) .{ }^{13} \mathrm{C}$ NMR $\left(d_{8}\right.$-THF $): \delta 174.8(\mathrm{Ph}), 162.8(\mathrm{C}=\mathrm{N})$, 151.8, 151.7, 141.8, 141.7, 140.5, 140.2, 138.2, 131.0, 128.3, 127.9, $126.3,125.5,123.9,123.7,120.8,120.8,120.6,109.1,104.4,91.2$ $(\mathrm{C} \equiv \mathrm{C}), 88.8(\mathrm{C} \equiv \mathrm{C}), 56.0,41.4,41.4,32.6,30.8,24.8,23.6\left(\mathrm{CH}_{2}\right)$, $14.5\left(\mathrm{CH}_{3}\right)$. Anal. Calc. for $\mathrm{C}_{142} \mathrm{H}_{150} \mathrm{~N}_{4} \mathrm{O}_{4} \mathrm{Zn}_{2} \cdot 6 \mathrm{H}_{2} \mathrm{O}: \mathrm{C}, 76.98 ; \mathrm{H}$, 7.37; N, 2.53. Found: C, 77.15; H, 7.46; N, 2.66\%.

Complex 11d. Complex 11d as a red powder was similarly prepared by the synthetic procedure as that of complex 11a with $70 \%$ yield. Spectroscopic data of 11d: ${ }^{1} \mathrm{H}$ NMR ( $d_{6}$-DMSO): $\delta$ $9.11(\mathrm{~s}, 4 \mathrm{H}, \mathrm{N}=\mathrm{CH}), 8.31(\mathrm{~s}, 2 \mathrm{H}, \mathrm{ArH}), 7.65\left(\mathrm{~d}, 4 \mathrm{H}, \mathrm{ArH},{ }^{4} J_{\mathrm{H}-\mathrm{H}}=\right.$ $2.2 \mathrm{~Hz}), 7.34\left(\mathrm{dd}, 4 \mathrm{H}, \mathrm{ArH},{ }^{3} J_{\mathrm{H}-\mathrm{H}}=6.3 \mathrm{~Hz},{ }^{4} J_{\mathrm{H}-\mathrm{H}}=2.3 \mathrm{~Hz}\right), 6.71$ $\left(\mathrm{d}, 4 \mathrm{H}, \mathrm{ArH},{ }^{3} \mathrm{~J}_{\mathrm{H}-\mathrm{H}}=8.8 \mathrm{~Hz}\right), 3.91(\mathrm{~s}, 4 \mathrm{H}, \mathrm{C} \equiv \mathrm{CH}) .{ }^{13} \mathrm{C} \mathrm{NMR}\left(d_{6^{-}}\right.$ DMSO): $\delta 172.5(\mathrm{Ph}), 162.4(\mathrm{C}=\mathrm{N}), 140.2,138.6,136.5,123.9$, 119.3, 109.8, 105.8, 84.0 (C $\equiv \mathrm{C}), 77.6(\mathrm{C} \equiv \mathrm{C}) . \mathrm{MS}(\mathrm{FAB}): \mathrm{m} / \mathrm{z}$ 777.2 (M+). Anal. Calc. for $\mathrm{C}_{42} \mathrm{H}_{22} \mathrm{~N}_{4} \mathrm{O}_{4} \mathrm{Zn}_{2} \cdot 6 \mathrm{H}_{2} \mathrm{O}: \mathrm{C}, 56.97 ; \mathrm{H}$, 3.87 ; N, 6.33. Found: C, 57.16; H, 3.75; N, 6.24\%.

Complex 11e. Complex 11e as a black powder was similarly prepared by the synthetic procedure as that of complex 11a with $60 \%$ yield. Spectroscopic data of 11e: ${ }^{1} \mathrm{H}$ NMR $\left(d_{8}\right.$-THF): $\delta 9.12$ (s, 4H, N=CH), 8.28 (s, 2H, ArH), 7.54 (br, 4H, ArH), 7.32 (d, $\left.4 \mathrm{H}, \mathrm{ArH},{ }^{3} J_{\mathrm{H}-\mathrm{H}}=8.8 \mathrm{~Hz}\right), 7.26\left(\mathrm{~d}, 8 \mathrm{H}, \mathrm{ArH},{ }^{3} J_{\mathrm{H}-\mathrm{H}}=8.6 \mathrm{~Hz}\right), 6.82$ (br, $4 \mathrm{H}, \mathrm{ArH}), 6.60\left(\mathrm{~d}, 8 \mathrm{H}, \mathrm{ArH},{ }^{3} J_{\mathrm{H}-\mathrm{H}}=8.6 \mathrm{~Hz}\right), 3.28(\mathrm{~m}, 16 \mathrm{H}$, $\left.\mathrm{CH}_{2}\right), 1.59\left(\mathrm{~m}, 16 \mathrm{H}, \mathrm{CH}_{2}\right), 1.35-1.30\left(\mathrm{~m}, 144 \mathrm{H}, \mathrm{CH}_{2}\right), 0.91-0.87$ (m, $24 \mathrm{H}, \mathrm{CH}_{3}$ ). Anal. Calc. for $\mathrm{C}_{162} \mathrm{H}_{234} \mathrm{~N}_{8} \mathrm{O}_{4} \mathrm{Zn}_{2} \cdot 6 \mathrm{H}_{2} \mathrm{O}$ : C, 74.94; H, 9.55; N, 4.32. Found: C, 75.12; H, 9.65; N, 4.42\%.

Complex 12. Complex 12 as a brown powder was similarly prepared by the synthetic procedure as that of complex 11a with $98 \%$ yield. Spectroscopic data of 12: ${ }^{1} \mathrm{H}$ NMR ( $d_{6}$-DMSO): $\delta$ $9.18(\mathrm{~s}, 4 \mathrm{H}, \mathrm{N}=\mathrm{CH}), 8.36(\mathrm{~s}, 2 \mathrm{H}, \mathrm{ArH}), 7.46$ (d, 4H, ArH, $\left.{ }^{3} J_{\mathrm{H}-\mathrm{H}}=7.8 \mathrm{~Hz}\right), 7.28\left(\mathrm{t}, 4 \mathrm{H}, \mathrm{ArH},{ }^{3} J_{\mathrm{H}-\mathrm{H}}=7.6 \mathrm{~Hz}\right), 6.73(\mathrm{~d}, 4 \mathrm{H}$, $\left.\mathrm{ArH},{ }^{3} J_{\mathrm{H}-\mathrm{H}}=8.6 \mathrm{~Hz}\right), 6.57\left(\mathrm{t}, 4 \mathrm{H}, \mathrm{ArH},{ }^{3} J_{\mathrm{H}-\mathrm{H}}=7.3 \mathrm{~Hz}\right) .{ }^{13} \mathrm{C} \mathrm{NMR}$ $\left(d_{6}\right.$-DMSO): $\delta 172.5(\mathrm{Ph}), 162.8(\mathrm{C}=\mathrm{N}), 138.6,136.1,134.5,123.3$, 119.5, $113.1(\mathrm{Ph})$. Anal. Calc. for $\mathrm{C}_{34} \mathrm{H}_{22} \mathrm{~N}_{4} \mathrm{O}_{4} \mathrm{Zn}_{2} \cdot 6 \mathrm{H}_{2} \mathrm{O}: \mathrm{C}, 51.73$; H, 4.34; N, 7.10. Found: C, 51.81; H, 4.38; N, 7.15\%.

Complex 13. Complex 13 as a brown powder was similarly prepared by the synthetic procedure as that of complex 11a with $60 \%$ yield. Spectroscopic data of 13: ${ }^{1} \mathrm{H}$ NMR ( $d_{6}$-acetone): $\delta$ $9.21(\mathrm{~s}, 4 \mathrm{H}, \mathrm{NCH}), 8.46(\mathrm{~s}, 2 \mathrm{H}, \mathrm{ArH}), 7.45\left(\mathrm{~d}, 4 \mathrm{H}, \mathrm{ArH},{ }^{4} J_{\mathrm{H}-\mathrm{H}}=\right.$ $2.6 \mathrm{~Hz}), 7.17\left(\mathrm{~d}, 4 \mathrm{H}, \mathrm{ArH},{ }^{4} J_{\mathrm{H}-\mathrm{H}}=2.6 \mathrm{~Hz}\right), 1.32\left(\mathrm{~s}, 36 \mathrm{H}, \mathrm{CH}_{3}\right) \cdot{ }^{13} \mathrm{C}$ NMR $\left(\mathrm{CDCl}_{3}\right): \delta 172.2(\mathrm{Ph}), 163.2(\mathrm{C}=\mathrm{N}), 142.4,139.6,134.9$, 130.0, 129.3, 119.4, 103.3, 36.2, 34.4, $31.8\left(\mathrm{CH}_{3}\right), 31.5\left(\mathrm{CH}_{3}\right)$. MS 
(FAB): $m / z 1130.19\left(\mathrm{M}^{+}\right)$. Anal. Calc. for $\mathrm{C}_{66} \mathrm{H}_{86} \mathrm{~N}_{4} \mathrm{O}_{4} \mathrm{Zn}_{2} \cdot 6 \mathrm{H}_{2} \mathrm{O}$ : C, 64.02; H, 7.98; N, 4.52. Found: C, 64.17; H, 8.11; N, 4.45\%.

1,3,5-Tris[(3-formyl]-4-hydroxyphenyl)ethynyl]benzene (14). A mixture of 1,3,5-triethynylbenzene $(300 \mathrm{mg}, 2.00 \mathrm{mmol}), 5$ bromosalicylaldehyde $(1325 \mathrm{mg}, 6.59 \mathrm{mmol}), \mathrm{Pd}\left(\mathrm{PPh}_{3}\right)_{2} \mathrm{Cl}_{2}$ $(70 \mathrm{mg}, 0.010 \mathrm{mmol})$ and $\mathrm{CuI}(11 \mathrm{mg}, 0.058 \mathrm{mmol})$ dissolved in $40 \mathrm{~mL}$ of $\mathrm{Et}_{3} \mathrm{~N}$ was stirred at $80^{\circ} \mathrm{C}$ for $24 \mathrm{hr}$ under nitrogen. After cooling to room temperature, the reaction mixture was poured into a $10 \%$ aqueous $\mathrm{NH}_{4} \mathrm{Cl}(50 \mathrm{~mL})$ solution and the product is extracted with $\mathrm{CH}_{2} \mathrm{Cl}_{2}(2 \times 60 \mathrm{~mL})$. The combined organic fraction was washed with water, dried over $\mathrm{MgSO}_{4}$. The crude product was purified by flash chromatography using a silica gel packed column by EA/hexanes (2:1) to yield $\mathbf{1 4}$ as yellow powder (25 mg, 2.5\%): Spectroscopic data of 14: ${ }^{1} \mathrm{H}$ NMR $\left(\mathrm{CDCl}_{3}\right) \delta 11.14$ (s, 3H, OH), $9.89(\mathrm{~s}, 3 \mathrm{H}, \mathrm{CH}=\mathrm{O}), 7.74(\mathrm{~s}, 3 \mathrm{H}, \mathrm{ArH}), 7.64(\mathrm{~d}, 3 \mathrm{H}$, $\left.\mathrm{ArH},{ }^{3} J_{\mathrm{H}-\mathrm{H}}=8.5 \mathrm{~Hz}\right), 7.61(\mathrm{~s}, 3 \mathrm{H}, \mathrm{ArH}), 7.00\left(\mathrm{~d}, 3 \mathrm{H}, \mathrm{ArH},{ }^{3} J_{\mathrm{H}-\mathrm{H}}=\right.$ $8.5 \mathrm{~Hz}) .{ }^{13} \mathrm{C} \mathrm{NMR}\left(\mathrm{CDCl}_{3}\right): \delta 192.4(\mathrm{CHO}), 163.0,139.7,135.7$, 134.7, 134.5, 125.2, 119.0, 114.5, $91.1(\mathrm{C} \equiv \mathrm{C}), 87.9(\mathrm{C} \equiv \mathrm{C})$. FABMS: $m / z$ 510.5 $\left(\mathbf{M}^{+}\right)$. Anal. Calc. for $\mathrm{C}_{33} \mathrm{H}_{18} \mathrm{O}_{6}: \mathrm{C}, 77.64 ; \mathrm{H}, 3.50$. Found: C, $77.71 ; \mathrm{H}, 3.56 \%$.

\section{Synthesis of trinuclear $\mathrm{Zn}$ (II)-salophen complexes}

Complex 15a. Compound $14(20 \mathrm{mg}, 0.039 \mathrm{mmol})$ and $\mathrm{Zn}(\mathrm{OAc})_{2} \cdot 2 \mathrm{H}_{2} \mathrm{O}(42 \mathrm{mg}, 0.19 \mathrm{mmol})$ dissolved in pyridine- $\mathrm{MeOH}$ $(30 \mathrm{~mL}-5 \mathrm{~mL})$ was stirred at $60^{\circ} \mathrm{C}$ for $30 \mathrm{~min}$ under nitrogen. Then to the resulting solution was slowly added $6 \mathbf{a}(38 \mathrm{mg}, 0.12 \mathrm{mmol})$ in $\mathrm{THF} /$ pyridine $(5 \mathrm{~mL} / 10 \mathrm{~mL})$, and the mixture was heated at $60^{\circ} \mathrm{C}$ for 2 days. After cooling to room temperature, the solvent was removed under vacuum and residue was washed with methanol, hexanes and ether. The product was collected by filtration to yield $15 \mathrm{a}$ as an orange powder $(35 \mathrm{mg}, 55 \%)$. Spectroscopic data of 15a: ${ }^{1} \mathrm{H}$ NMR $\left(d_{6}\right.$-DMSO): $\delta 9.45(\mathrm{~s}, 3 \mathrm{H}, \mathrm{N}=\mathrm{CH}), 9.13(\mathrm{~s}, 3 \mathrm{H}$, $\mathrm{N}=\mathrm{CH}), 8.45$ (s, 3H, PyrH), 8.33 (s, 3H, PyrH), 7.77 (s, 3H, $\mathrm{ArH}), 7.71$ (s, 3H, ArH), 7.59-7.31 (m, 18H, ArH), 7.09 (s, 3H, thiophene), $6.76\left(\mathrm{~d}, 6 \mathrm{H}, \mathrm{ArH},{ }^{3} J_{\mathrm{H}-\mathrm{H}}=8.2 \mathrm{~Hz}\right) .{ }^{13} \mathrm{C}$ NMR $\left(d_{6}-\right.$ DMSO): $\delta 173.7(\mathrm{Ph}), 172.7(\mathrm{Ph}), 163.8(\mathrm{C}=\mathrm{N}), 162.8(\mathrm{C}=\mathrm{N})$, 149.5, 149.3, 146.7, 141.1, 140.1, 137.5, 136.6, 134.3, 131.3, 127.7, 127.6, 124.9, 124.4, 124.2, 123.8, 123.4, 122.9, 119.6, 119.1, 106.0, 105.7, $93.7(\mathrm{C} \equiv \mathrm{C}), 91.8(\mathrm{C} \equiv \mathrm{C}), 85.5(\mathrm{C} \equiv \mathrm{C}), 79.9(\mathrm{C} \equiv \mathrm{C})$. Anal. Calc. for $\mathrm{C}_{87} \mathrm{H}_{45} \mathrm{~N}_{9} \mathrm{O}_{6} \mathrm{~S}_{3} \mathrm{Zn}_{3} \cdot 9 \mathrm{H}_{2} \mathrm{O}: \mathrm{C}, 59.14 ; \mathrm{H}, 3.59 ; \mathrm{N}, 7.13 ; \mathrm{S}$, 5.44. Found: C, 59.27; H, 3.66; N, 7.25; S, 5.57\%.

Complex 15b. Complex 15b as an orange powder was similarly prepared from 6a by the same synthetic procedure as that for complex $15 \mathrm{a}$ with $50 \%$ yield. Spectroscopic data of $15 \mathrm{a}:{ }^{1} \mathrm{H}$ NMR $\left(d_{8}\right.$-THF): $\delta 9.64(\mathrm{~s}, 3 \mathrm{H}, \mathrm{N}=\mathrm{CH}), 9.02(\mathrm{~s}, 3 \mathrm{H}, \mathrm{N}=\mathrm{CH}), 8.44(\mathrm{~d}, 3 \mathrm{H}$, $\left.\mathrm{PyrH},{ }^{3} J_{\mathrm{H}-\mathrm{H}}=3.5 \mathrm{~Hz}\right), 8.22\left(\mathrm{~d}, 3 \mathrm{H}, \mathrm{PyrH},{ }^{3} J_{\mathrm{H}-\mathrm{H}}=6.3 \mathrm{~Hz}\right), 7.72$ $7.28(\mathrm{~m}, 39 \mathrm{H}, \mathrm{ArH}), 6.85\left(\mathrm{~d}, 6 \mathrm{H}, \mathrm{ArH},{ }^{3} J_{\mathrm{H}-\mathrm{H}}=8.5 \mathrm{~Hz}\right), 2.03(\mathrm{t}$, $\left.12 \mathrm{H}, \mathrm{CH}_{2},{ }^{3} J_{\mathrm{H}-\mathrm{H}}=8.1 \mathrm{~Hz}\right), 1.15-1.05\left(\mathrm{~m}, 36 \mathrm{H}, \mathrm{CH}_{2}\right), 0.77(\mathrm{t}, 18 \mathrm{H}$, $\left.\mathrm{CH}_{3},{ }^{3} J_{\mathrm{H}-\mathrm{H}}=7.2 \mathrm{~Hz}\right), 0.62\left(\mathrm{~m}, 12 \mathrm{H}, \mathrm{CH}_{2}\right) \cdot{ }^{13} \mathrm{C}$ NMR $\left(d_{8}\right.$-THF): $\delta 173.7(\mathrm{Ph}), 172.8(\mathrm{Ph}) 162.7(\mathrm{C}=\mathrm{N}), 162.2(\mathrm{C}=\mathrm{N}), 150.1,149.9$, 149.6, 145.9, 140.1, 138.9, 137.1, 136.4, 134.0, 131.3, 129.5, 129.4, 126.6, 126.2, 124.6, 124.3, 123.9, 123.7, 123.1, 122.3, 122.1, 119.2, 119.0, 118.9, 118.9, 118.7, 115.4, 107.3, $90.5(\mathrm{C} \equiv \mathrm{C}), 89.6(\mathrm{C} \equiv \mathrm{C})$, 87.1 $(\mathrm{C} \equiv \mathrm{C}), 82.2(\mathrm{C} \equiv \mathrm{C})$. Anal. Calc. for $\mathrm{C}_{150} \mathrm{H}_{135} \mathrm{~N}_{9} \mathrm{O}_{6} \mathrm{Zn}_{3} \cdot 9 \mathrm{H}_{2} \mathrm{O}$ : C, 71.55; H, 6.12; N, 5.00. Found: C, 71.71; H, 6.20; N, 5.18\%.

\section{Acknowledgements}

Financial support provided by the National Science Council of Taiwan is grateful acknowledged. Funding for the instrumentation facility of the department of chemistry of NTU has also been provided in part by the National Science Council of Taiwan. We also thank Dr I-Jui Hsu for helpful comments on the quantum mechanical calculation and Mr Meng-Ju Yang for the lifetime study and measurement.

\section{References}

1 W. H. Leung, E. Y. Y. Chan, E. K. F. Chow, I. D. Williams and S. M. Peng, J. Chem. Soc., Dalton Trans., 1996, 1229-1236.

2 D. A. Atwood and M. J. Harvey, Chem. Rev., 2001, 101, 37-52.

3 G. A. Morris, H. Zhou, C. L. Stern and S. T. Nguyen, Inorg. Chem., 2001, 40, 3222-3227.

4 M. Bandini, P. G. Cozzi and A. Umani-Ronchi, Chem. Commun., 2002, 919-927, and references therein.

5 L. Canali and D. C. Sherrington, Chem. Soc. Rev., 1999, 28, 85-93.

6 N. Y. Ito and T. Katsuki, Bull. Chem. Soc. Jpn., 1999, 72, 603-619.

7 T. Katsuki, Curr. Org. Chem., 2001, 5, 663-678.

8 For reviews: $(a)$ N. Sträter, W. N. Lipscomb, T. Klabunde and B. Krebs, Angew. Chem., Int. Ed. Engl., 1996, 35, 2024-2055; (b) D. E. Wilcox, Chem. Rev., 1996, 96, 2435-2458; (c) H. Steinhagen and G. Helmchen, Angew. Chem., Int. Ed. Engl., 1996, 35, 2339-2442.

9 Representative examples: (a) M. J. Young and J. Chin, J. Am. Chem. Soc., 1995, 117, 10577-10578; (b) P. Molenveld, S. Kapsabelis, J. F. J. Engbersen and D. N. Reinhoudt, J. Am. Chem. Soc., 1997, 119, 2948 2949; (c) W. H. Chapman and R. Breslow, J. Am. Chem. Soc., 1995, 117, 5462-5469; (d) J. C. M. Ritter and R. G. Bergman, J. Am. Chem. Soc., 1998, 120, 6826-6827; (e) T. Arai, Y. M. A. Yamada, N. Yamamoto, H. Sasai and M. Shibasaki, Chem.-Eur. J., 1996, 2, 1368-1372, and references therein.

10 R. G. Konsler, J. Karl and E. N. Jacobsen, J. Am. Chem. Soc., 1998, 120, 10780-10781.

11 (a) A. C. W. Leung, J. H. Chong, B. O. Patrick and M. J. MacLachlan, Macromolecules, 2003, 36, 5051-5054; (b) C. Ma, A. Lo, A. Abdolmaleki and M. J. MacLachlan, Org. Lett., 2004, 6, 3841-3844.

12 (a) S.-S. Sun, C. L. Stern, S. T. Nguyen and J. T. Hupp, J. Am. Chem. Soc., 2004, 126, 6314-6326; (b) G. A. Morris, H. Zhou, C. L. Stern and S. T. Nguyen, Inorg. Chem., 2001, 40, 3222-3227; (c) K. E. Splan, A. M. Massari, G. A. Morris, S.-S. Sun, E. Reina, S. T. Nguyen and J. T. Hupp, Eur. J. Inorg. Chem., 2003, 2348-2351.

13 (a) K.-H. Chang, C.-C. Huang, Y.-H. Liu, Y.-H. Hu, P.-T. Chou and Y.-C. Lin, Dalton Trans., 2004, 1731-1738; (b) H.-C. Lin, C.-C. Huang, C.-H. Shi, Y.-H. Liao, C.-C. Chen, Y.-C. Lin and Y.-H. Liu, Dalton Trans., 2007, 781-791.

14 A. W. Kleij, D. M. Tooke, A. L. Spek and J. N. H. Reek, Eur. J. Inorg. Chem., 2005, 4626-4634.

15 (a) O. Karthaus, K. Ueda, A. Yamagushi and M. Shimomura, J. Photochem. Photobiol., A, 1995, 92, 117-120; (b) D. D. Mysyk, I. F. Perepichka and N. I. Sokolov, J. Chem. Soc., Perkin Trans. 2, 1997, 537-546.

16 (a) I. F. Perepickha, D. D. Mysyk and N. I. Sokolov, in Current Trends in Polymer Photochemistry, ed. N. S. Allen, M. Edge, I. R. Bellobono and E. Selli, Ellis Horwood, Chichester, UK, 1995, pp. 318-327; (b) M. Matsui, K. Shibata, H. Muramatsu and H. Nakazumi, J. Mater. Chem., 1996, 6, 1113-118; (c) D. D. Mysyk, I. F. Perepichka, D. F. Perepichka, M. R. Bryce, A. F. Popov, L. M. Goldenberg and A. J. Moore, J. Org. Chem., 1999, 64, 6937-6950; (d) I. F. Perepichka, A. F. Popov, T. V. Orekhova, M. R. Bryce, A. M. Andrievskii, A. S. Batsanov, J. A. K. Howard and N. I. Sokolov, J. Org. Chem., 2000, 65, 3053-3063.

17 (a) K.-T. Wong, Y.-Y. Chien, R.-T. Chen, C.-F. Wang, Y.-T. Lin, H.H. Chiang, P.-Y. Hsieh, C.-C. Wu, C.-H. Chou and Y. O. Su, J. Am. Chem. Soc., 2002, 124, 11576-11577; (b) W.-L. Yu, J. Pei, W. Huang and A. J. Heeger, Adv. Mater., 2000, 12, 828-831; (c) S. Setayesh, A. C. Grimsdale, T. Weil, V. Enkelmann, K. Müllen, F. Meghdadi, E. J. W. List and G. Leising, J. Am. Chem. Soc., 2001, 123, 946-953.

18 K. Sonogashira, Comprehensive Organic Synthesis, ed. B. M. Trost and I. Fleming, Pergamon, New York, 1991, vol. 3, pp. 521-549. 
19 (a) K. Sonogashira, Y. Tohda and N. Hagihara, Tetrahedron Lett., 1975, 16, 4467-4470; (b) T. Hundertmarl, A. F. Littke, S. L. Buchwald and G. C. Fu, Org. Lett., 2000, 2, 1729-1731.

20 R. I. Kureshy, N. H. Khan, S. H. R. Abdi, S. T. Patel and R. V. Jasra, Tetrahedron: Asymmetry, 2001, 12, 433-437.

21 M. Nielsen, A. H. Thomsen, T. R. Jensen, H. J. Jakobsen, J. Skibsted and K. V. Gothelf, Eur. J. Org. Chem., 2005, 342-347.
22 (a) C.-C. Kwok, S.-C. Yu, I. H. T. Sham and C.-M. Che, Chem. Commun., 2004, 2758-2579; (b) C.-M. Che, S.-C. Chan, H.-F. Xiang, M. C. W. Chan, Y. Liu and Y. Wang, Chem. Commun., 2004, 1484-1485. 23 (a) A. N. Fletcher, Photochem. Photobiol., 1969, 9, 439-444; (b) K. Nakamaru, Bull. Chem. Soc. Jpn., 1982, 55, 2697-2705.

24 E. Weber, M. Hecker, E. Koepp, W. Orlia, M. Czugler and I. Csöregh, J. Chem. Soc., Perkin Trans. 2, 1988, 1251-1257. 